\title{
INTEGRATION MAINTENANCE: THE UNCONSTITUTIONALITY OF BENIGN PROGRAMS THAT DISCOURAGE BLACK ENTRY TO PREVENT WHITE FLIGHT
}

\author{
Rodney A. Smolla*
}

I. The Mechanics and Semantics of Integration

MAINTENANCE ...................................... 893

A. The Sociological Debate Over Tipping ............. 893

1. The Convergent-Expectation Model ............. 893

2. The Empirical Evidence..................... 895

3. The Role of Future Expectations and Fear ........ 897

B. Community Plans to Prevent Tipping .............. 898

II. The Illegality of INTEgRation Maintenance ....... 901

A. An Overview: The Confusing Matrices of Bakke and Fullilove ..................................... 901

B. The Statutory Context: An Overview of Section 1982 and Title VIII ............................... 907

C. The Governmental Objectives Underlying Integration Maintenance................................. 912

1. The Immediate Emphases: Altering the Racial Balance and Limiting Black Entry............. 912

2. The Ulterior Interests: Utilitarianism and the Universalist Ethic ........................... 913

D. The Countervailing Interests: The Impact on Personal Rights....................................... 915

E. Ethnic Identity and Freedom of Choice ............. 917

F. Choice and the Right to Travel ................... 920

G. Bakke and Fullilove Applied ................... 925

1. Predicating Policy on Avoiding White Flight ...... 926

2. Racial Balance in Housing as an End in Itself ..... 933

H. Race Consciousness and the Real Estate Industry ..... 936

III. Conclusion........................................ 939

* Assistant Professor of Law, University of Illinois College of Law. B.A. 1975, Yale University; J.D. 1978, Duke University. 
As black entry into traditionally white suburbs has increased, ${ }^{1}$ a growing number of communities have adopted or considered "integration-maintenance" plans, programs that seek to limit or channel black entry. ${ }^{2}$ Integration-maintenance plans are a product of the fear that unless government controls black migration, white residents in the communities experiencing a substantial influx of blacks will flee, leavmg communities that are all or predoninantly black. ${ }^{3}$ Such plans seek to prove wrong the cynical judgment that residential integration exists only in the interval between the entry of the first black family into a neighborhood and the departure of the last white family. ${ }^{4}$

This article exammes the legality of integration maintenance under the Constitution and relevant federal statutes. ${ }^{5}$ Section I reviews the sociological theory and evidence underlying integration-maintenance plans and the various forms of integration inaintenance. Section II evaluates the legality of integration maintenance. The section begins with an overview of Supreme Court decisions involving "benign" government programs based on classification according to race and then

1. In the 1970s black migration from the central cities became "effectively directed towards the suburbs." U.S. Dep'T of Housing \& URban Development, Recent Suburbanization of BLACKS 13 (1979). Since 1970 the number of blaeks living in suburbs bas increased in several of the nation's largest cities. Id. Despite the mcreases, black access to suburbs remains restricted in many metropolitan areas. Id. 20,26. In these metropohtan areas, the black population continues to be concentrated in central cities rather than in suburbs: over $76 \%$ of all blacks in metropolitan commumities live in central cities, although only about $40 \%$ of all whites in the metropolitan area live in central cities. U.S. BuREAU of THE CeNSUS, U.S. Dep'T OF CoMmerCE, ANNUAL HousING SURVEY I977: INDICATORS OF HOUSING AND NEIGHBORHOOd QUALITY 1 (1979) (Table A1).

2. See generally Ackerman, Integration for Subsidized Housing and the Question of Racial Occupancy Controls, 26 STAN. L. Rev. 245 (1974); Bittker, The Case of the Checker-Board Ordinance: An Experiment in Race Relations, 71 YALE L.J. 1387 (1962); Navasky, The Benevolent Housing Quota, 6 How. L.J. 30 (1960); Note, The Benign Housing Quota: A Legitimate Weapon to Fight White Flight and Resulting Segregated Communities?, 42 FordHAM L. Rev. 891 (1974); Note, Benign Steering and Benign Quotas: The Validity of Race-Conscious Government Policies to Promote Residential Integration, 93 HARv. L. REv. 938 (1980); Note, Benign Quotas, 20 WAYNE L. REv. 1109 (1974); Note, Tipping the Scales of Justice: A Race-Conscious Remedy for Neighborhood Transition, 90 YALE L.J. 377 (1980). Integration-maintenance plans and the issues discussed in this article nnay affect ethnic, cultural, or racial minorities other than blacks. Bccause efforts to control minority entry into suburbs have historically centered on relations between blacks and whites, however, this article is phrased in that context.

3. See generally Frey, Central City White Flight: Racial and Nonracial Causes, 44 AM. Soc. Rev. 425 (1979); Goering, Neighborhood Tipping and Racial Transition: A Review of Social Science Evidence, 44 J. AM. INST. Planners 68, 70-76 (1978); Schelling, A Process of Residential Segregation: Neighborhood Tipping, in Racial Discrimination In Economic LifE 157-84 (A. Pascal ed. 1972).

4. See Klem, Urban Irony: Some Integrated Towns Draw Fire for Efforts to Keep Racial Balance, Wall St. J., Jan. 8, 1979, at 1, col. 1 .

5. The two relevant federal statutes are the Civil Rights Act of 1866, 42 U.S.C. $\$ 1982$ (1976), and the Fair Housing Act, 42 U.S.C. $\$ \$ 360 I-3619$ (1976). 
reviews the pertinent provisions of federal anti-discrimination laws. The section then summarizes the principal competing interests implicated by integration maintenance. It does so by explaining the practical and philosophical justifications that can be advanced to defend the concept and by examining the impact of imtegration maintenance on personal rights, including the right to travel and the right of free association. The section then discusses the legitimacy of predicatimg governmental policy on the avoidance of white flight and the validity of pursuing racial balance im housing as an end $\mathrm{m}$ itself. The final section examines, from a practical perspective, the impact of integration maintenance on the goal of eliminating invidious race consciousness from the real estate industry.

This article concludes that despite the cominonsense appeal of imtegration maintenance, the concept cannot be reconciled with anti-discrimination statutes or with the Constitution. Although the purpose of integration maintenance is to promote "integration," its effect is to undermine the proscriptions of fair-housing laws. This article argues that recent Supreme Court decisions allowing governmental use of racial classifications for "bemign" purposes do not permit the use of classifications when they adversely affect ininority groups, despite laudatory social or political goals. The Supreme Court's limited approval of "bemgn" discrimination does not include the pursuit of racial balance as an end in itself and does not permit governmental programs that restrict minority-group opportunity in an effort to avoid white flight.

\section{The Mechanics and Semantics of INTEGRATION MAINTENANCE}

\section{A. The Sociological Debate Over Tipping.}

1. The Convergent-Expectation Model. "Tipping" is a sociological term that describes the tendency of white families to abandon residential areas once the black population exceeds a certain critical "tipping point," resulting in a neighborhood that is overwhelmingly black. ${ }^{6}$ Tipping can be conceptualized individually, as the exit poimt

6. See, e.g., Ackerman, supra note 2, at 251; Goering, supra note 3, at 68; Kaplan, Equal Justice in an Unequal World: Equality for the Negro-The Problem of Special Treatment, $61 \mathrm{Nw}$. U.L. REv. 363, 390 (1966); Navasky, supra note 2, at 34-37; Schelling, supra note 3, at 159-68. In Trinity Episcopal School Corp. v. Romney, 387 F. Supp. 1044 (S.D.N.Y. 1974), rev'd on other grounds, 523 F.2d 88 (2d Cir. 1975), the court attempted to give the tipping concept precise judicial definition: "the tipping point of a community is that point at which a set of conditions has been created that will lead to the rapid flight of an existing majority class under circumstances of instability which result in the deterioration of the neighborhood environment." Id. at 1065-66. The court listed thrce criteria for determining whether an area has reached or is approaching the tipping poimt: 
for a single family, ${ }^{7}$ or collectively, as the exit point for the white population of a whole community. ${ }^{8}$ Professor Thomas Schelling describes tipping in terms of converging individual expectations. ${ }^{9}$ Because of the group dynamics of tipping, even a relatively low percentage of black entry coupled with the normal operation of individual tipping points in the community can cause a self-accelerating reaction resulting in the departure of virtually all whites. ${ }^{10}$ Professor Schelling describes the community tipping point as "a watershed-a point of black entry prior to which white residency is a self-sustaining condition and beyond which white departure is a self-sustaining process." 11

To illustrate Schelling's convergent-expectation inodel, hypothesize an all-white community consisting of 1,000 housing units. Assume that $5 \%$ of the community has a very low tipping point and is unwilling to tolerate the entry of even one black family. Another 25\% of the residents is willing to tolerate a black influx of 5\% to $20 \%$. Assume that the remainder of the community will tolerate black entry so long as the black population remains below $30 \%$, but that a substantial number of whites will exit if the black population exceeds $30 \%$. Assume also that once the black population exceeds 50\%, all remaining whites will reach their tipping points and leave. Under this model the entry of only a handful of black families can create an inexorable movement to $100 \%$ black population. ${ }^{12}$ Although $70 \%$ of the community is willing to tolerate substantial black entry, the interaction of individual tipping points triggers a series of exoduses. The immediate departure of $5 \%$ of the population causes an additional $25 \%$ of the community to leave. This transition creates a community that is approximately $30 \%$ black. At this point the rate of racial changeover rises dramatically. ${ }^{13}$ In Professor Schelling's words, the existence of a "frequency distribution of the tolerance of the original white residents for the black ininority"

(1) the gross numbers of minority group families or families in a measurable economic or social group which are likely to affect adversely [a]rea conditions; (2) the quality of community services and facilities; and (3) the attitudes of majority group residents who might be persuaded by their subjective reactions to the first and second criteria to leave the [a]rea.

Id. at 1066.

7. See Ackerman, supra note 2, at 251-53; Schelling, supra note 3, at 160-61.

8. See Ackerman, supra note 2, at 251-53; Navasky, supra note 2, at 34; Schelling, supra note 3 , at $166-68$.

9. Schelling, supra note 3 , at $163-68,177-78$.

10. Id. 166-69.

11. Id. 166.

12. See Ackerman, supra note 2, at 253; Schelling, supra note 3, at 161-68; Note, Benign Steering, supra note 2, at 941-43.

13. See Ackerman, supra note 2 , at 252-53. 
leads to "a spiral or domino effect, or unraveling process." 14

2. The Empirical Evidence. Although the convergent-expectation model is useful in explaining the nathematics of tipping, it does not explain the forces that cause individuals to leave nor does it explain how to compute or predict the critical-mass level of black entry at which a neigliborhood precipitously tips. ${ }^{15}$ The literature is striking for its lack of unanimity on what the tipping point for most comınunities is likely to be. As early as 1960 , Victor Navasky collected at least eight estimates of the usual community tipping point, ranging from $20 \%$ to $60 \%$ of the black population. ${ }^{16}$ Estimates have since then proliferated with nost being in the $20 \%$ to $30 \%$ range. ${ }^{17}$

Available evidence is inconclusive regarding whether tipping always accompanies black entry. Sociologist Jolın Goering writes that "[t]he evidence on the tipping phenomenon, such that exists, is scattercd and impressionistic,"18 and there exist "very few data witll which to definitively answer the question of whether neiglıborlioods tip."19 Although there appears to be a consensus that tipping occurs in some neighborhoods, ${ }^{20}$ available evidence does not establish whether the considerations that lead to tipping are primarily racial or economic. ${ }^{21}$ Similarly, the data go no furtlier than Schelling's nodel in predicting the point at which any given neighborhood is likely to tip ${ }^{22}$ or in explaining whether in general certain levels of black population lead inexorably to tipping. ${ }^{23}$

It is clcar that a range of considerations, soine overtly racial and soine not, leads to tipping, and that the mix and intensity of the considerations vary significantly ainong neiglıborlıoods. ${ }^{24}$ Racial intolerance,

\footnotetext{
14. Schelling, supra note 3, at 160-61 (footnote omitted).

15. Goering, supra note 3, at 69-70.

16. See Navasky, supra note 2, at 34-37.

17. See Note, Benign Steering, supra note 2, at 942.

18. Goering, supra note 3, at 69.

19. Id.

20. See, e.g., Ackerman, supra note 2, at 251-60; Navasky, supra note 2, at 31-37; Note, Benign Steering, supra note 2, at 940-44.

21. See Frey, supra note 3, at 443-44; Goering, supra note 3, at 71-77.

22. See Ackerman, supra note 2, at 255; Goering, supra note 3, at 69-70; Grodzins, Metropolitan Segregation, ScIENTIFIC AM., Oct. 1957, at 33, 34 ("The tip point' varies from city to city and neighborhood to neighborhood").

23. See Goering, supra note 3, at 69 . Goering is extremely skeptical of the accuracy of social sciencc data on tipping. He writes that "[s]ocial science has no capacity at present to generate any iron laws regarding the rate of racial resideutial change" and that there "is no single demographic proportion of nonwhites to whites which can be used as an a priori basis for predicting the timing or rate of white fight." Id. 69-70.
}

24. See id. 70-77. 
population growth rates, employment opportunities, housing costs, the availability of financing, the organization of local real estate boards, traditions of local real estate agents, attitudes of neighborhood organizations, the quality of local government services, the financial status of residents, and the commumity's proximity to other racially identifiable neighborhoods all appear to influence the rate of racial changeover. ${ }^{25}$ In some communities the demographic composition seens to change overnight. In others substantial numbers of blacks are able to enter a community with no visible exodus of whites, and the community is apparently able to maintain a stable denographic balance.

The Chicago metropolitan area provides an example of the widely differing experiences that suburban communities inay have with black entry. One recent study categorized the integrated Chicago-area suburbs as follows: (1) "formerly white, slowly integrating"; (2) "formerly white, rapidly piling up"; (3) "fornerly inoderately integrated, stabilizing"; (4) "fornierly substantially integrated, rapidly consolidatimg"; and (5) "ghettoizing." 26 All suburbs depicted as "ghettoizing" are south of Chicago and have black populations ranging from $85 \%$ to $97 \% .27$ Among the "slowly integrating" suburbs are Oak Park and Park Forest, each with black populations near 8\%.28 And ainong the "forinerly moderately integrated and stabilizing" suburbs are Evanston and Waukegan, each with black populations of approximately $17 \% .^{29}$ The Chicago-area experience does not prove that the convergent-expectation model is inaccurate, but it does illustrate that generalizations about the degree and rate of demographic change in communities are difficult

25. Id. $70-76$.

26. See Olmstead, Black Shift to Suburbs is Growing, Chicago Sun-Times, Nov. 30, 1980, at 3, col. 1. The Olmstead article summarizes the results of an unpublished study dated Nov. 1980 by Professor Pierre DeVise, a sociologist at the University of Illinois, Circle Campus. See also P. DeVise, Racial Steering and a Community's Right to Remain Integrated (Aug. 1980) (Chicago Regional Inventory Working Paper II).

27. The four suburbs listed as "ghettoizing" had the following black population levels: East Chicago Heights, 97.9\%; Robbins, 97.7\%; Phoenix, 91.1\%; Dixmoor, 84.4\%. Olmstead, supra note 26 , at 3 , col. 1 .

28. The "slowly integrating" suburbs and their black populations are: Country Club Hills, 6.2\%; Glenwood, 6.6\%; Hazel Crest, 7.7\%; Oak Park, 8.1\%; Park Forest, 7.8\%. Id.

29. The communities characterized as "formerly moderately integrated, stabilizing," had the following levels of black entry: Chicago Heights, 26.6\%; Evanston, 17.7\%; Joliet, 20\%; Waukegan, 17.1\%. Id. Overall, Chicago's black population rose from $32.7 \%$ in 1970 to $39 \%$ in 1978, while the Chicago suburban black population rose from $4 \%$ to $5 \%$ during the saine period. Id. The De Vise data appears to support Goering's arguments that tipping is not a universal phenomenon and that the consequences of initial black eutry into suburbs varies substantially from community to cominunity. Goering, supra note 3, at 76-77. Concerning neighborltoods withim cities, the Hyde Park area of Chicago is frequently cited as an example of an integrated neighborlood that has apparently inaintained a relatively stable racial composition despite substantial black entry. Goering, supra note 3 , at 73 . 
to make. Social science simply cannot accurately predict the tipping point for any given community.

3. The Role of Future Expectations and Fear. In explaining the divergent reactions of communities to black entry, fear of future neighborhood conditions appears to play a greater role in precipitating tipping than dispassionate assessinents of present neighborhood conditions. ${ }^{30}$ It has often been noted that the entry of only one black family into an area can create a inassive evacuation of whites. ${ }^{31}$ Such sudden racial changeover occurs when the fears of white families in a community are sufficiently intense to make tipping a self-fulfilling prophecy. ${ }^{32}$

Sociologists and legal scholars agree that fear plays a disproportionately large role in the process of racial changeover. Goering notes that "[p]eople appear to be making decisions about what they think will happen in the future rather than im relationship to existing proportions of non-whites in an area." 33 Navasky states that "[b]ecause whites fear inundation they flee, opening nrore space into which minority groups rush. If they didn't fear, they wouldn't flee and there would be no inundation." ${ }^{34}$ Schelling depicts the tipping phenomenon as a vicious circle of fear: "the more it occurs the more it will be expected, and the more it is expected the more it will occur." 35 And Bruce Ackerman writes that

[i]f differing individual white tolerances for black neighbors and jittery white expectations are tipping's prinary causes, then tipping points will vary according to the attitudinal composition of a given white population and the differing arrangements of environmental factors which could trigger uncontrolled white fears that an irrevocable chain of turnover has begun. ${ }^{36}$

In short, fear compounds the uncertainties inherent in any effort to control the racial changeover process in a community. Community planners who attempt to devise controls must contend with the lack of hard sociological data on which generalizations about commumity behavior can be made. They must also acknowledge that any given com-

30. See Ackerman, supra note 2, at 255; Schelling, supra note 3, at 159; Note, Benign Steering, supra note 2, at 943.

31. See Navasky, supra note 2, at 31.

32. See J. HeChT, BeCAUSE It Is Right 34-35 (1970); Goering, supra note 3, at 76; Navasky, supra note 2, at 32; Schelling, supra note 3, at 177-78; Note, Benign Steering, supra note 2, at 943.

33. Goering, supra note 3 , at 76 . Goering proceeds, however, to warn of the difficulties of explaining tipping purely in sociopsychological terms. $I d$.

34. Navasky, supra note 2 , at 32 .

35. Schelling, supra note 3 , at 177.

36. Ackerman, supra note 2, at 255 . 
munity's reaction to black entry is determined largely by the community's collective sociopsychological profile, a subject on which rehable data will almost certainly not exist.

\section{B. Community Plans to Prevent Tipping.}

The integration-maintenance concept arose against the backdrop of the convergent-expectation theory of tipping. The concept's proffered justification is simple: "by limiting the number of Negroes allowed into an integrated area to a percentage below the tipping point, integration will be preserved." 37 If controls on black entry are designed to keep the black population just beneath the tipping point, then the "limit on black nunibers could provide a suitable racial mix for the coinplementary nuniber of whites already resident."38 By curbing black entry, white fear is decreased and neighborhood racial changeover is inhibited. ${ }^{39}$ Integration maintenance is thus seen as a necessary, commonsense expedient to prevent resegregation.

The nost direct approach to integration maintenance is to place explicit limits on the sale or rental of housing to blacks. The village of Oak Park, Illinois considered in 1974 the adoption of an ordinance containing the following provision:

It shall be unlawful for any seller or any agent to knowingly sell any real property to a black person on any block in the designated area if thirty (30\%) per cent or more of the block between two intersecting streets on both sides of the street has been occupied by black persons. ${ }^{40}$

The proposed Oak Park ordinance contained a parallel (30\%) limitation on the rental to blacks of units within individual-apartment buildimgs. ${ }^{41}$ The proposed ordinance further provided that any black person refused housmg because of the ordmance could contact the village's community relations department, which would assist applicants

37. Kaplan, supra note 6, at 391.

38. Schelling, supra note 3, at 168.

39. Professor Ackerman thus concludes that the "government is not likely to abuse the authority to einploy housing integration quotas," and that on balance integration-maintenance controls are desirable "for dealing with the sensitive issue of housing integration." Ackerman, supra note 2, at 309. Professor Ackerman's article focuses primarily on racial control of public lousing projects, id. 245-49, but his conclusious appear to apply with equal force to control outside of the confines of public housing. Id. 308-09. See also Note, Benign Steering, supra note 2, at 964-65.

40. The proposed ordinance, entitled "An Ordinance Amending thc Fair Housing Ordinance of the Village of Oak Park and Establishing Procedures for Achieving Stable Integrated Housing Patterns," is reprimted in part in Note, The Use of Racial Housing Quotas to Achieve Integrated Communities: The Oak Park Approach, 6 LoY. CHI. L.J. 164, 164-65 n.3 (1975).

41. Id 
in locating coinparable housing in other areas of Oak Park. ${ }^{42}$ Finally, the proposed ordinance required the community relations department to help owners find white persons to purchase or lease real estate in the designated area. ${ }^{43}$ The Oak Park Board of Trustees rejected the ordinance by a vote of eight to seven..$^{44}$

A less rigorous approach to integration maintenance is to encourage or discourage, rather than prohibit, the entry of certain groups into designated areas. This approach can vary in rigidity and racial emphasis. A community can choose to establish definite targets for racial composition, sucli as a $30 \%$ black population limit. Real estate agents would be required to encourage white entry whenever the black population exceeded $30 \%$ and to encourage black entry whenever the black population fell below that level. A community can choose a more fluid and less racially explicit alternative, sucli as requiring encourageinent of the entry of racial groups "underrepresented" in a community in relation to some larger geographic unit-the entire metropolitan community, the state, or the nation. The encouraged racial group will vary according to the racial demographics of the community and the shifting of larger geographic population units. Navasky describes such a plan as the "mirror" approacl. ${ }^{45}$

In 1977 the Chicago suburb of Park Forest South adopted a mirror plan. The Park Forest South ordinance required real estate brokers to develop "affirmative marketing plans" to encourage the entry of racial groups that were underrepresented in the community as coinpared to that group's representation in the Chicago-inetropolitan area. ${ }^{46}$ When the suburb passed the ordimance, blacks constituted $25 \%$ of the population of Park Forest South, but accounted for ouly $20 \%$ of the Chicago metropolitan area population. 47 The effect of the Park Forest Soutlr ordmance was to compel real estate brokers to encourage whites, not blacks, to move into the suburb. ${ }^{48}$ Park Forest South lias since re-

\section{2. $I d$.}

43. Id.

44. Sce Lauber, Integration Takes More Than a Racial Quota, PLANnIng, Apr.-May 1974, at $15-16$.

45. Navasky labels such relational approaches to achieving desired racial compositions "mirror quotas" because they embrace the idea that the proportion of whites to nonwhites in a community should "mirror that of another white-nonwhite population in the larger context." Navasky, supra note 2, at 47. See also Klem, supra note 4, at 14, col. 1; Reinhold, Integrated Suburbs Now Fearful of Not Drawing Enough Whites, N.Y. Times, Apr. 9, 1979, § D, at 10, col. 5.

46. Klem, supra note 4, at 14, col. I; Reinhold, supra note 45, § D, at 10, col 5; Note, Benign Steering, supra note 2, at 945.

47. Klem, supra note 4, at 14 , col. 1 .

48. Id; Note, Benign Steering, supra note 2, at 945. 
scinded the ordinance. ${ }^{49}$

A third form of integration inaintenance is the race-conscious dispersal of entrants throughout a community. This type of plan encourages whites to nove into areas that already contain some blacks and encourages blacks to move into areas that are predommantly white. In Shaker Heights, Ohio the housing office of Shaker Heights acts as a governmental real estate agency. The housing office gratuitously provides prospective buyers with house histings and escorts those buyers to view listed hoines. . $^{50}$ The housing office's listing and escort services, however, are divided into two separate racial tracks. ${ }^{51}$ Blacks are given free assistance only when they seek entry into predommantly white neighborhoods. Similarly, whites are denied the office's services unless they are willing to nove into already integrated neighborhoods. ${ }^{52}$ As in the Park Forest South program, the practical effect of the Shaker Heights plan is to einphasize the recruitinent and placement of whites. ${ }^{53}$

The variety of forms that integration-maintenance plans can take complicates the evaluation of their legality. Individual communities inay devise any nuinber of plans with varymg degrees of exclusion, racial explicitness, and governmental intervention. The community can choose alnong the various attributes of the prototypical inodels. The choices will reflect a wide variety of social, political, economic, and legal judgnents unique to each community. Nevertheless, all integration-maintenance plans share three essential characteristics: (1) they treat prospective entrants in a commumty differently on a racially selective basis; $; 4$ (2) their objective is the avoidance of white flight; 55 and thus (3) they attempt to some degree to discourage black entry. ${ }^{56} \mathrm{Al}-$ though this article discusses the legal consequences of various integration-maintenance plans, the article primarily exammes the legality of

49. See Klein, supra note 4, at 14, col. 1 . The village rescinded the ordinance in response to a complaint challenging the ordinance filed with the Department of Housing and Urban Developinent by local realtors. See id.

50. Note, Benign Steering, supra note 2, at 945.

51. Id. $945-46$.

52. Id.

53. "[T]he [Housing] Office [of Shaker Heights] openly adınits the necessity of devoting 'the major part of its efforts to the introduction of whites into areas with a disproportionate minority population." Id. 946 (quoting Shaker Heights Housing Office, Inpleinentation Procedures (n.d.)). The Oak Park Housing Center, a private organization, currently operates a program similar to that of Shaker Heights. Id. 945 n.55.

54. See notes 37-53 supra and accompanying text and notes 260-68 infra and accoinpanying text.

55. See text accoinpanying note 39 supra.

56. See notes 37-40 supra and accompanying text and notes 123-29 infra and accompanying text. 
the central characteristic common to all integration-maintenance plans: the use of differential racial treatment to prevent white flight.

\section{The Illegality of Integration Maintenance}

A. An Overview: The Confusing Matrices of Bakke and Fullilove. In Regents of the University of California v. Bakke ${ }^{57}$ and in Fullilove v. Klutznick ${ }^{58}$ the Supreme Court held that some forms of governmental race-conscious activity are permissible under the equal protection clause. The Justices produced eleven separate opinions in Bakke and Fullilove. ${ }^{59}$ Apparently the Burger Court is as divided as academe and American society at large on precisely how to address the government's "ameliorative" use of race. ${ }^{60}$ Despite the multiplicity of opinions in the

57. 438 U.S. 265 (1978).

58. 448 U.S. 448 (1980). The "reverse-discrimmation" question had reached the Court prior to Fullilove and Bakke in DeFuuis v. Odegaard, 416 U.S. 312 (1974), a case in which a white male challenged a minority-admissions program at the University of Washington School of Law. The special-admissions program reserved a portion of the law school class for blacks, Chicanos, American Indians, and Filipinos. The Court did not reach the merits, holding in a 5-4 decision that the case was moot because DeFunis was registered for the final term of his third year of law school by the time the case was argued in the Supreme Court. Justice Douglas, dissenting on the mootness issue, reached the merits. He wrote that the program was unconstitutional, stating that the law school must treat each applicant "in a racially neutral way." Id. at 334 (Douglas, J., dissenting) (emphasis in original). Justice Douglas adopted a color-blind equal protection standard, writing that "[i]f discrimination based on race is constitutionally permissible when those who hold the reins can come up with 'compelling' reasons to justify it, then constitutional guarantees acquire an accordian-like quality." Id. at 343 (Douglas, J., dissenting).

59. The Justices authored six separate opinions in Bakke: Justice Powell announced the judgment of the Court, Regents of the Univ. of Cal. v. Bakke, 438 U.S. 265 (1978); Justices Brennan, White, Marshall, and Blackmun joined in an opinion concurring in part and dissenting im part, id. at 324; Justice White also authored a separate opinion, id. at 379; as did Justice Marshall, id. at 387, and Justice Blackmun, id. at 402; and Justice Stevens wrote an opinion concurring in part and dissenting in part, $i d$. at 408. In Fullilove the Justices authored five opinions: Chief Justice Burger announced the judgment of the Court, Fullilove v. Klutznick, 448 U.S. 448 (1980); Justice Powell authored a separate concurring opinion, id. at 495; Justices Marshall, Brennan, and Blackmun joined in another concurring opmion, $i d$. at 517 ; Justice Rehnquist joined Justice Stewart in dissent, $i d$. at 552; and Justice Stevens authored a separate dissenting opinion, id. at 532.

60. Professor Vincent Blasi has criticized Bakke as a "disturbing failure by the Court to discharge its responsibility to give coherent, practical meaning to our most important constitutional ideas." Blasi, Bakke as Precedent: Does Mr. Justice Powell Have a Theory?, 67 CALIF. L. Rev. 21, 21 (1979). Professor Blasi finds it troublesome that "the justices [sic] seem to have profited so little from the unusually rich scholarly literature on the subject of racial preferences." Id. Professor Blasi correctly characterizes the academic hterature on racial classifications as unusually ricl, and the Supreme Court's lack of a clear consensus in Bakke, and later in Fullilove, is undeniable. That lack of consensus, however, may be as much a refiection of the academic literature as a rejection of it, for the divisions on the Court largely parallel the divisions annong scholars. The literature in the area is extensive. See, e.g., B. BITTKER, THE CASE FOR BLACK Reparations (1973); R. Dworkin, Reverse Discrimination, im TAKINg RIghts SERIousLy 223 (1977); N. Glazer, Affirmative Discrimination (1975); Reverse Discrimination (B. Gross ed. 1977); Baldwin \& Nagan, Board of Regents v. Bakke: The All-American Dilemma Revisited, 30 U. FLA. 
two cases, certain critical areas of consensus among the Justices have emerged.

A clear majority exists on the Court in support of three positions: (1) some use of race in governmental programs is permissible, but its use is limited to programs that are "remedial"; (2) the term remedial refers only to programs that enhance minority opportunity in response to the lingering effects of past racial discrimination; and (3) even remedial race-conscious programs are illegal if they are not well tailored to effectuate their remedial purposes. If the opinions in Bakke and Fullilove are reduced to their lowest cominon denominator, even those Justices who are the most lenient im approving the remedial use of race would absolutely prohibit race-conscious programs that reinforce racial stereotypes, promote racial separatism, or ask minorities to bear the brunt of the social cost of a "benign" program.

The Court squarely rejected the position Justice Harlan articulated in his dissent in Plessy v. Ferguson, 61 that "[o]ur Constitution is colorblind."62 In Bakke the petitioner, Alan Bakke, challenged the validity of a special admissions program for minority students at the medical school of the University of Califorma at Davis. Four members of the

L. Rev. 843 (1978); Bell, Bakke, Minority Admissions, and the Usual Price of Racial Remedies, 67 CALIF. L. Rev. 3 (1979); Boxhill, The Morality of Preferential Hiring, 7 Phllosophy \& PUB. AfF: 246 (1978); Brest, The Supreme Court, 1975 Term-Foreword: In Defense of the Antidiscrimination Principle, 90 HARv. L. REv. 1 (1976); Dixon, Bakke: A Constitutional Analysis, 67 CAL1F. L. Rev. 69 (1979); Ely, The Constitutionality of Reverse Racial Discrimination, 41 U. CHI. L. REv. 723 (1974); Greenawalt, Judicial Scrutiny of "Benign" Racial Preference in Law School Admissions, 75 Colum. L. Rev. 559 (1975); Greenawalt, The Unresolved Problems of Reverse Discrimination, 67 CALIF. L. Rev. 87 (1979); Gunther, The Supreme Court, 1971 Term-Foreword: In Search of Evolving Doctrine on a Changing Court: A Model for a Newer Equal Protection, 86 HaRv. L. Rev. 1 (1972); Hastie, Affirmative Action in Vindicating Civil Rights, 1975 U. ILL. L.F. 502; Kaplan, supra note 6; Karst, The Supreme Court, 1976 Term-Foreword: Equal Citizenship Under the Fourteenth Amendment, 91 HARv. L. Rev. 1 (1977); Karst \& Horowitz, Affirmative Action and Equal Protection, 60 VA. L. Rev. 955 (1974); Morris, Equal Protection, Affirmative Action and Racial Preferences in Law Admissions: DeFunis v. Odegaard, 49 WASH. L. Rev. 1 (1973); O'Neil, Bakke in Balance: Some Preliminary Thoughts, 67 CALIF. L. Rev. 143 (1979); O'Neil, Racial Preference and Higher Education: The Larger Context, 60 VA. L. Rev. 925 (1974); Posner, The Bakke Case and the Future of "Affirmative Action," 67 CALIF. L. Rev. 171 (1979); Posner, The DeFunis Case and the Constitutionality of Preferential Treatment of Racial Minorities, 1974 Sup. CT. REv. 1; Ravenell, DeFunis \& Bakke . . . The Voice Not Heard, 21 How. L. J. 128 (1978); Sandalow, Racial Preferences in Higher Education: Political Responsibility and the Judicial Role, $42 \mathrm{U}$. CH1. L. REv. 653 (1975); Sedler, Racial Preference, Reality and the Constitution: Bakke v. Regents of the University of California, 17 SANTA CLARA L. REv. 329 (1977); Seeburger, A Heuristic Argument Against Preferential Admissions, 39 U. PITT. L. Rev. 285 (1977); Tribe, Perspectives on Balkke: Equal Prolection, Procedural Fairness, or Siructural Justice?, 92 HARv. L. REV. 864 (1979); Van Alstyne, Rites of Passage: Race, the Supreme Court, and the Constitution, 46 U. CHI. L. REv. 775 (1979).
61. 163 U.S. 537 (1896).
62. Id. at 559 (Harlan, J., dissenting). 
Court, Justices Brennan, White, Marshall, and Blackmnn, voted to uphold the special-admissions program, stating that the "[g]overnment may take race into account when it acts not to demean or insult any racial group, but to remedy disadvantages cast on minorities by past racial prejudice . . . ."63 Justice Powell, who cast the critical swing vote in Bakke, agreed with these Justices that government may in some circumstances use race as a selective criterion. He held, however, that the particular race-conscious program used by the Davis Medical School was constitutionally impermissible because it tended to pursue racial preference for its own sake, rather than for valid educational reasons. ${ }^{64}$ The remaining four Justices never reached the constitutional issue, holding that the Davis program violated Title VI of the Civil Rights Act of 1964,65 which they construed to be color-blind.66 Thus, the peculiar judicial compromise in Bakke approved in principle the government's use of race as a selective criterion, but struck down the particular racially selective program before the Court.

In Fullilove, Bakke's theoretical approval of race-conscious governmental activity was given the Supreme Court's imprimatur in fact. Seven Justices agreed that the government could engage in race-conscious activity in some circumstances, and six Justices approved the specific race-conscious program that was at issue. Fullilove involved the validity of the Minority Busmess Enterprise (MBE) provision of the Public Works Employment Act of 1977,67 a congressional spending program that required, absent an administrative waiver, that ten percent of the federal funds granted under the program for public works projects be used to procure services or supplies from busmesses owned and controlled by members of statutorily defined minority groups. 68 Chief Justice Burger, who was joined by Justices White and Powell,

63. 438 U.S. at 325 (Brennan, White, Marshall, \& Blackmun, JJ., concurring in part and dissenting in part).

64. Id. at 307-20 (Powell, J.). Justice Powell's critical differentiation between the use of racial balance for its own sake and its use as a consideration incident to the pursuit of academic pluralism is discussed in detail at text accompanying notes 250-53 infra.

65. Civil Rights Act of 1964, 42 U.S.C. $\$ 2000$ d (1976).

66. See 438 U.S. at 421 (Stevens, J., concurring in part and dissenting in part, joined by Burger, CJ., Stewart, \& Rehnquist, JJ.).

67. 42 U.S.C. $\$ 6705(1)(2)$ (Supp. III 1979). The Act provides that

[e]xcept to the extent that the Secretary [of Commerce] determines otherwise, no grant shall be made under this chapter for any local public works project unless the applicant gives satisfactory assurance to the Secretary that at least 10 per centum of the amount of each grant shall be expended for minority business enterprises. For purposes of this paragraph, the term "minority business enterprise" means a business at least 50 per centum of which is owned by mimority group inembers .... [F]or the purposes of the preceding sentence, minority group members are citizens of the United States who are Negroes, Spanish-speaking, Orientals, Indians, Eskimos, and Aleuts.

68. Id. 
announced the judgment of the Court and flatly rejected the contention that " $m$ the remedial context the Congress must act in a wholly colorblind fashion." 69 Justices Marshall, Brennan, and Blackmun adhered to their position in Bakke and approved of the government's use of race to "provide benefits to minorities for the purpose of remedying the present effects of past racial classification."70 Justice Stevens, though finding the $\mathrm{MBE}$ provision unconstitutional, refrained from embracing a color-blind standard. ${ }^{71}$ Only two members of the Fullilove Court, Justices Stewart and Relinquist, held that the Constitution is colorblind - that it countenances absolutely no use of race-conscious activity by the government. ${ }^{72}$

Every Justice who reached the constitutional issue in both Bakke and Fullilove refused to accept at face value the government's assertion that the program did in fact remedy the present effects of past discrimination, and imstead attempted to penetrate beneath labels to ensure that the particular program did in fact effectuate genumely remedial objectives. ${ }^{73}$ A program that does not in fact enhance the opportunities of minorities will not survive the scrutiny of the Court under any of the tests discussed below.

The Court's consensus is not undercut by the division among the Justices regarding the exact standard of review. Justice Powell stands alone in his clear adherence to the "strict-scrutiny" test as traditionally articulated: the government's racial classifications are imvahd unless

69. 448 U.S. at 482.

70. Id. at 518 (Marshall, J., concurring) (footnote omitted).

71. Id at 552 (Stevens, J., dissenting).

72. Id. at 522-32 (Stewart, J., dissenting). Referring to Justice Harlan's dissent in Plessy, Justice Stewart wrote that Justice Harlan's "colleagues disagreed with him, and held that a statutc that required the separation of people on the basis of their race was constitutionally valid because it was a 'reasonable' exercise of power and had been 'enacted in good faith for the promotion [of] the public good .... ." Id at 523 (quoting Plessy v. Ferguson, 163 U.S. 537, 550 (Harlan, J., dissenting)). Justice Stewart then noted that the Court's approval of the provision in Fullilove was premised on unuch the same deference to a legislative classification enacted in good faith for the promotion of the public good. 448 U.S. at 523. See also Van Alstyne, supra note 60, at 780-83, $792-810$.

73. Thus, no matter low the attitude of a particular Justice toward the programs in either Bakke or Fullilove is described, it is inpossible to cliaracterize the activity of every Justice in those two cases as anything other than rigorous examination of the purposes and effects of the "remedial" program at issue. Every opimion in Bakke and Fullilove is an exercise in scrutiny; every Justice who wrote in those two decisions extensively explored the purposes and the effects of programs involved. It is a fiction to presunne that because Justices Brcnnan, Marshall, and Blackmun have adopted the "intermcdiate test," the rigor of their individual exanninations of the programs in Bakke and Fullilove was any less searching than that of Justice Powell. See Fullilove v. Klutznick, 448 U.S. 448, 517-20 (1980) (Marsluall, J., concurring); Regents of the Univ. of Cal. v. Bakke, 438 U.S. 265, $358-59$ (1978) (Brennan, White, Marsliall, and Blackmun, JJ.). See text accolnpanying notes $82-87$ infra. 
they are made in pursuit of "compelling" governmental objectives and are "narrowly tailored" to achieve those objectives. ${ }^{74}$ Three Justices, Brennan, Marshall, and Blackmun, have adopted a two-tier analysis. They apply the strict-scrutiny test to racial classifications that are "invidious" but apply a more relaxed "intermediate" standard of review when they perceive the race-conscious activity at issue as remedial or benign. ${ }^{75}$ Under their intermediate test, the government's objectives need be merely "important," rather than "compelling," and need be only "substantially related," rather than "narrowly tailored," to the accomphishment of the objectives. ${ }^{76}$

Chief Justice Burger and Justices White and Stevens apparently have abandoned precise articulations of the standard of review. Chief Justice Burger's opinion in Fullilove expressly eschewed the adoption of any of the competing "formulas of analysis," 77 and Justices White and Stevens apparently agree with the Chief Justice that the formulas are not of much assistance in deciding cases. ${ }^{78}$ Nevertheless, those three

74. Fullilove v. Klutznick, 448 U.S. 448, $495-99$ (1980) (Powell, J., concurring); Regents of the Univ. of Cal. v. Bakke, 438 U.S. 265, $269-320$ (1978) (Powell, J.). The "strict-scrutiny" test dates back to Koreinatsu v. United States, 323 U.S. 214, 216 (1944). In Korematsu the Court applied the test to validate the internment of Japanese Americans in camps in westeru states during World War II. Ironically, the Korematsu decision was the only case prior to Fullilove in which the Court sustained an explicit governmental race regulation. See Van Alstyne, supra note 60, at 793 u. 62 .

75. Fullilove v. Klutznick, 448 U.S. 448, 517-19 (1980) (Marshall, J., concurring); Regents of the Univ. of Cal. v. Bakke, 438 U.S. 265, 325, 356-79 (1978) (Brennan, White, Marshall, \& Blackinun, JJ., concurring in part and dissenting in part). In 1972 Gerald Gunther first discerned the evolution of an "intermediate" standard of review in benign race and sex discrinination cases. Gunther, supra note 60 , at $20-48$. The test is described as "intermediate" because it is less rigorous than the "strict-scrutiny" test but nore rigorous than the "ratioual-basis" standard that is usually applied to equal protection cases nivolvnig classifications that implicate only economic interests. See, e.g., Williamson v. Lee Optical Co., 348 U.S. 483 (1955); Daniel v. Family Security Life Ins. Co., 336 U.S. 220 (1949); Railway Express Ageucy, Inc. v. New York, 336 U.S. 106 (1949); Kotch .v. Board of River Port Pilot Counin'rs, 330 U.S. 552 (1947).

76. Fullilove v. Klutznick, 448 U.S. 448, 517-19 (1980) (Marsliall, J., concurring); Regents of the Univ. of Cal. v. Bakke, 438 U.S. 265, 356-79 (1978) (Breıman, White, Marshall, \& Blackmun, $\mathrm{JJ}$., concurring in part and dissenting in part).

77. 448 U.S. at 492 (Burger, C.J.).

78. Justice White, of course, joined Chief Justice Burger's opimion in Fullilove, and, unlike Justice Powell, did not qualify his coucurreuce concerning the proper standard of review. Justice Stevens, in his Fullilove dissent, appeared to agree with the Chief Justice's statements concerning the proper test for review. Id. at 552 n.29 (Stevens, J., dissenting).

Chief Justice Burger's standard, if read literally, applies the "narrowly-tailored" requirement that forms the second prong of the traditional strict-scrutiny test, but eliminates any judicial judginent of the importance of the governmeutal objectives other than a determination of whether the objectives are within the power of the government entity adopting them. Thus, Burger's opimion makes no atteinpt to weigh the significance of the objectives underlying the MBE progrant, but instead focuses on whether the program was within Cougress's power pursuant to the commerce clause, the speuding clause, or the enforcentent clauses of the fourteenth and fifteenth amendinents. Id. at 473-80 (Burger, C.J.). By contrast, it is clear from Justice Stevens's opimion that his 
Justices do apply a test that is identical to the second prong of the strict scrutiny test: they require that a prograin be narrowly tailored to the effectuation of its goal. ${ }^{79}$ The Chief Justice and Justice White deviate sharply from the conventional strict scrutiny formula, however, in refusing to test the importance of the government's goal. They ask only whether the government has the power under the Constitution to adopt the objective. ${ }^{80}$

Justices Brennan, Marshall, and Blackmun have been the most permissive Justices in approving race-conscious activity by the government. ${ }^{81}$ Even those three Justices have, however, repeatedly emphasized the difference between genuinely remedial programs and programs that are enacted in a good-faith belief that they are benign, but because of their notives, assumptions, or effects, are rendered impermissible. In Bakke Justice Brennan stated that the Davis Medical School's plan did not "contravene the cardinal principle that racial classifications that stigmatize-because they are drawn on the presumption that one race is inferior to another or because they put the weight of government behind racial hatred and separatisn1-are invalid without more." 82 His opinion also stated that a plan is not benign merely because the legislature so believes: " "TT]he mere recitation of a benign, compensatory purpose is not an automatic shield," "83 and "the

application of the Burger formula entails a substantial evaluation of the governmental objectives. Id. at 532-48 (Stevens, J., dissenting). Thus, Stevens shares with Burger only a frustration with equal protection formulas; Stevens's substantive position in Fullilove is contrary to Burger's.

79. The Chief Justice stated that there must be careful judicial evaluation and "a most searching examination" to ensure that any program employing race-conscious activity is "narrowly tailored to achieve its objectives" of remedying the present effects of past discrimination. 448 U.S. at $490-91$.

80. Id. at 490 . See note 78 supra.

81. It is possible to rank the Justices of the Supreme Court serving at the time of Fullilove and Bakke on a continuum according to their apparent attitudes toward race-conscious activity by government. At the least permissive extreme are Justices Stewart and Rehnquist, who adhere to absolute color-blindness. Next along the continuum is Justice Stevens, who is ambiguous in his acceptance of any definitive formula but who, judging froin his open hostility to the MBE program in Fullilove, would apparently lold most racial classificatious invalid. Next is Justice Powell, the only Justice joining the Burger opinion in Fullilove who insisted on strict scrutiny. Justice Powell approved the racial classification in Fullilove but rejected the classification in Bakke. Justices Burger and White are difficult to place on the scale because of their impatience with articulated standards of review. They both appear measurably less rigorous in their assessment of racial classifications than Justice Powell. Justice White voted to approve the program in Bakke, while Justice Powell did not, and neither Justice White nor the Chief Justice have accepted Powell's strict-scrutimy position. The most lenient Justices are Marshall, Brennan, and Blackmun. All apply the intermediate standard of review to racial classifications that they perceive as "reinedial," and all voted to approve the race-conscious programs in both Bakke and Fullilove. It is impossible to predict the approach Justice $O^{\prime}$ Connor will take toward such cases.

82. 438 U.S. at $357-58$.

83. Id. at 358 (quoting Califano v. Webster, 430 U.S. 313,317 (1977)). 
line between honest and thoughtful appraisal of the effects of past discrimination and paternahistic stereotyping" is not always clear. ${ }^{84}$ Articulatimg a concern critical to the integration-maimtenance debate, the opinion indicated terse agreenent that state programs ostensibly designed to ameliorate the effects of past discrimination risk creating stigma, "since they inay proinote racial separatism and reinforce the views of those who beheve that members of racial minorities are inherently incapable of succeeding on their own."85

In addition to distinguishing truly reinedial programs from those that stigmatize, Justice Marshall in Fullilove differentiated programs that disadvantage whites relative to blacks and prograins that disadvantage blacks relative to whites. Whites, unlike blacks, are " not saddled with such disabilities, or subjected to such a history of purposeful unequal treatment, or relegated to such a position of pohtical powerlessness as to cominand extraordinary protection froin the majoritarian pohtical process." "86 The three Justices seemed aware of the problems arising from remedial programs that whites design and einphatically adhered to the principle that "any statute inust be stricken that . . . singles out those least well represented in the pohtical process to bear the brunt of a bemign prograin." 87

It would seriously distort the Bakke and Fullilove decisions to interpret them as authorizing in broad terms the government's good-faith use of race. To the contrary, both decisions evince a general hostility toward racial classifications, but except programs that convincingly deinonstrate a sound connection to reinedying the effects of past discrimination. Simce the Bakke and Fullilove decisions, the lower courts, consistent with this narrow interpretation, have uniformly held that programs usimg racially restrictive quotas must satisfy Justice Powell's rigorous strict-scrutiny test to survive constitutional challenge. ${ }^{88}$

\section{B. The Statutory Context: An Overview of Section 1982 and Title VIII.}

No analysis of the use of race as a selective criterion by local governments im the housing context can ignore congressional legislation

84. 438 U.S. at 360.

85. $I d$.

86. 448 U.S. at 518 (Marshall, J., concurring) (quoting Regents of the Univ. of Cal. v. Bakke, 438 U.S. 265, 357 (1978) (Breunan, White, Marshall, \& Blackmun, JJ., concurring in part and dissenting in part)).

87. 438 U.S. at 361.

88. See Johnson v. Board of Educ., 604 F.2d 504, 515 n.5 (7th Cir. 1979), vacated and remanded for further consideration in light of suggestion of mootness, 449 U.S. 915 (1980); Parent Ass'n v. Ambach, 598 F.2d 705, 717 (2d Cir. 1979). 
concerning racial discrimination in the real estate market. The question of the consistency of integration inaintenance with federal-fairhousing laws involves issues that parallel the issues in the constitutional debate: Are federal-fair-housing laws intended to achieve racial balance or merely to eliminate invidious discrimination; and whatever their purpose, do they perimit restrictions on minority-group choice to achieve it?

In enacting the Civil Rights Act of $1866,{ }^{89}$ which is currently embodied in section 1982 of the United States Code, ${ }^{90}$ Congress declared in apparently unequivocal language that "[a]ll citizens of the United States shall have the same right, in every State and Territory, as is enjoyed by white citizens thereof to inherit, purchase, lease, sell, hold and convey real and personal property." 91 In the 1968 watershed decision, Jones v. Alfred H. Mayer Co.,92 the Supreine Court held that section 1982 prohibits "all discrimination against Negroes in the sale or rental of property-discrimination by private owners as well as discrimination by public authorities." 93

Two inonths before the Jones decision, Congress had enacted the Fair Housing Act, embodied in Title VIII of the Civil Rights Act of 1968.94 In its opening section the statute declares that "[i]t is the policy of the United States to provide, within constitutional himitations, for fair housing throughout the United States."95 The operative provisions of Title VIII are contained in section 3604,96 which defines and makes unlawful five separate types of racially discriminatory activity. Subsections (a) and (b) of section 3604 provide that it is unlawful to deny "a dwelling to any person because of race, color, rehigion, sex, or national origin"97 or "to discriminate in the terms, . . . or in the provision of services or facilities"98 associated with the sale or rental of real estate.

\footnotetext{
89. 42 U.S.C. § 1982 (1976).

90. Id.

91. Id.

92. 392 U.S. 409 (1968).

93. Id. at 421 .

94. 42 U.S.C. $\$ \S 3601-3619$ (1976).

95. Id. $\$ 3601$.

96. Id. $\S 3604$. Section 3604(a), the most frequently used section, makes it unlawful "[t]o refuse to sell or rent after the making of a bona fide offer, or to refuse to negotiate for the sale or rental of, or otherwise make unavailable or deny, a dwelling to any person because of race, color, religion, sex, or national origin." Section 3604(b) makes it unlawful "[ $t$ ]o discriminate against any person in the terms, conditions, or privileges of sale or rental of a dwelling, or in the provision of services or facilities in connection therewith, because of race, color, religion, sex, or national

97. Id. $\$ 3604(\mathrm{a})$. See note 96 supra.

98. 42 U.S.C. \& 3604(b) (1976). See note 96 supra.
} origin." 
The operative provisions of section 1982 and Title VIII flatly prohibit the consideration of race in the sale and rental of housing in the United States. Construed strictly by the lower courts, Title VIII, like Title VII of the Civil Rights Act of 1964, ${ }^{99}$ proscribes activity with discriminatory effects, even if the agent or homeowner has no subjective intent to discriminate. ${ }^{100}$ A violation of Title VIII can thus "be proved without establishing a malevolent or unlawful intent . . . . [and] allegedly benign motivation . . cannot provide a defense."101 In Zuch $v$. Hussey, ${ }^{102}$ a groundbreaking decision, the district court held that section 3604(a) prohibits brokers from exerting any effort "to steer or channel a prospective buyer into or away from an area because of race."103

Some courts and commentators have suggested that differential treatment according to race in the housing niarket does not violate Title VIII if such treatnient is undertaken pursuant to the mandate of an integration-inaintenance statute. ${ }^{104}$ The rationale is that because integration-maintenance plans seek to preserve racial balance, they further the goal of the statute. ${ }^{105}$ This argument is based primarily on a remark by Senator Walter Mondale, the chief sponsor of the statute, that the goal of the Act is to establish "truly integrated and balanced living patterns,"106 and receives added support froni Justice Powell's stateinents in his opinion for the Court in Gladstone, Realtors $v$. Village of Bellwood.107 The Court held in Gladstone that the village of Bellwood and four white individual homeowners living in Bellwood had standing to sue two brokerage firms that were allegedly engaged in steering blacks toward a previously integrated area of the town and in steering whites away from that area, toward the predommantly white areas of the village. 108 Justice Powell noted that " $[t]$ he adverse consequences attendant upon a 'changing' neighborhood can be profound." 109 Racial steering, Powell stated, may reduce the total nuniber of prospective

99. 42 U.S.C. $\$ \S 2000$ e-2000e-17 (1976).

100. See, e.g., Fox v. United States Dep't of Hous. and Urban Dev., 468 F. Supp. 907, 915 (E.D. Pa. 1979).

101. United States v. Reece, 457 F. Supp. 43, 48 (D. Mont. 1978) (citations omitted).

102. 394 F. Supp. 1028 (E.D. Mich. 1975).

103. Id. at 1047. See generally Note, Racial Steering: The Real Estate Broker and Title VIII, 85 YALE L.J. 808 (1976).

104. See Barrick Realty, Inc. v. City of Gary, 491 F.2d 161, 164-65 (7th Cir. 1974); Note, Benign Steering, supra note 2, at 960-63.

105. See note 104 supra.

106. 114 CoNG. ReC. 3422 (1968).

107. 441 U.S. 91 (1979).

108. Id. at 115.

109. Id. at 110 . 
buyers in the area, thereby causing diminished prices. "This phenomenon would be exacerbated," Powell wrote, "if perceptible increases in the minority population directly attributable to racial steering precipitate an exodus of white residents." 110 Finding standing to challenge real estate practices that "have begun to rob Bellwood of its racial balance and stability . . .,"111 Powell quoted the Court's statement in Linmark Associates v. Township of Willingboro"112 that " 'there can be no question about the importance' . . . of 'promoting stable, racially integrated housing." "113

The remarks of Senator Mondale and the cominents of the Court in Gladstone, when considered in context, do not support integration inaintenance. Title VIII was enacted in a truncated legislative process im which no committee reports were issued, and the Court has stated that the legislative history is not helpful to understanding the Act. ${ }^{114}$ The language of Title VIII on its face, however, appears to be colorblind. Also, nothing in the Act or history of its passage suggests that Congress in 1968 ever considered providing an exception for government activity limiting minority group access to suburbs in the name of racial balance.

After the enactinent of Title VIII, Jean Dubofsky, a legislative assistant to Senator Mondale, wrote an article ${ }^{115}$ detailing the historical circumstances of the enactinent. Although Dubofsky's account is not "legislative history," it does explain the political atmosphere out of which Title VIII energed and strongly indicates that the sponsors of the Act intended only to attack exclusionary racial barriers, not to provide exceptions atteinpting to prevent white flight:

The most persuasive of the arguments advanced by the liberals [sponsoring the bill] was the one that segregated housing is the simple rejection of one human being by another without any justification but superior power. No matter a man's university degrees, his income level, his profession, he could suffer the degradation and humiliation of being told he was not good enough to live in a white neighborhood. At a time when riots threatened to close down every inajor city in the country and black militants preached the basic indecency of white America, a fair housing law could ease the frustration of blacks and the role of the law as a teacher might overcome the

110. Id.

111. $I d$.

112. 431 U.S. 85 (1977).

113. 441 U.S. at 111 (quoting Linmark Assocs. v. Township of Willingboro, 431 U.S. 85, 94 (1977)).

114. Trafficante v. Metropolitan Life Ins. Co., 409 U.S. 205, 210 (1972).

115. Dubofsky, Fair Housing: A Legislative History and a Perspective, 8 WASHBURN L.J. 149 (1969). 
ignorance and fear of whites which previously had blocked attempts to lower a black-white barrier. ${ }^{116}$

Similarly, the Gladstone decision affirms the national opposition to racial steering. The decision provides no support for the reintroduction of racial steering under the label of "benign" activity. Given Justice Powell's statements im Bakke that racial balancing for its own sake is unconstitutional, 117 and that racially explicit legislation is not entitled to greater judicial deference because it is characterized as benign, ${ }^{118}$ his opinion in Gladstone cannot be read as an endorsement of benign governmental steering. Indeed, the underpinnings of Gladstone are subtly, but dispositively, antithetical to imtegration maintenance.

Gladstone was decided in the aftermath of Trafficante v. Metropolitan Life Insurance Co., ${ }^{119}$ in which the Court leld that a group of whites had standing to sue for the removal of restrictions on black access to their apartment louse. ${ }^{120}$ As Bruce Ackerınan has pointed out, "Trafficante, which upholds open and free black access says nothing about the constitutional status of white efforts to achieve or preserve integration by limiting black access to certain housing." 121

What is true of Trafficante is true of Gladstone: the cases that grant whites standing to open suburbs to blacks cannot properly be invoked to deny blacks access. Justice Powell wrote in Gladstone that the white residents had standing because they lived in a neighborhood "whose racial composition allegedly [was] being manipulated . . . ."122 It is an inversion of logic to argue that because Trafficante and Gladstone permit whites who favor black entry to sue to strike down barriers to entry, murncipalities that fear the exit of whites who disfavor black entry can enact new barriers to black entry, thereby avoiding an exodus of prejudiced or fearful whites. The legal interest recognized in Gladstone and Trafficante is the interest all citizens share in living in communities that are not racially skewed because of discrimination; it is not the mterest in living in a community no more than $30 \%$ black.

116. Id. 154.

117. Regents of the Univ. of Cal. v. Bakke, 438 U.S. 265, 307 (1978). See notes 57-66 supra and accompanying text.

118. Id. at 294-95.

119. 409 U.S. 205 (1972).

120. Id. at 212.

121. Ackerman, supra note 2 , at $300 \mathrm{n} .257$.

122. Gladstone, Realtors v. Village of Bellwood, 441 U.S. 91,114 (1979) (emphasis added). The Court recognized that a neighborhood "may be so extensive in area, so heavily or even sparsely populated, or so lacking in shared social and commercial intercourse that there would be no actual injury to a particular resident." $I d$. 
C. The Governmental Objectives Underlying Integration Maintenance.

To evaluate the constitutionality of integration maintenance, the objectives underlying the concept nust be defined with precision. The definitional process requires two steps: a practical evaluation of the immcdiate functional objectives common to all integration-maintenance plans and an exploration of the philosophical underpinnings of the intergration-maintenance concept.

1. The Immediate Emphases: Altering the Racial Balance and Limiting Black Entry. In adopting an integration-inaintenance program the community by definition seeks to achieve a different racial composition from what it believes would result in the absence of such a program. It is counter-intuitive to suppose that a community would intervene in the housing inarket in a race-conscious manner unless it planned to alter the demographics of the community. It is difficult to conceive of a community attempting to "maintain" integration without first postulating the existence of an implicit or explicit goal, either vaguely or precisely defined, representing the commumity's desired racial balance.

The target may reflect a purely sociological hypothesis and be fixed at the point beyond which the community believes large-scale white flight will result. The target may reflect a combination of sociological prediction and normative judgment; it may reflect the level of black entry that is perceived as ideal or equitable. To the extent that a commumity seeks to fix a target level for black population below the tipping point, its efforts are, as previously noted, largely guesswork, for it is virtually impossible to predict the tipping point of a particular commumity. ${ }^{123}$

Some targets are demonstrably the product of normative judgments that transcend sociological predictions. For example, the target chosen under the "mirror" approach, in which a suburb seeks to have its own black population reflect the black population of a larger geographic entity such as the whole inetropolitan area, ${ }^{124}$ has no direct connection with any sociological prediction of the local tipping

\footnotetext{
123. According to Professor Kaplan:

[A]ny law which attempts to specify a general tipping poimt will be subject to enormous error since that point-if it exists at all-will probably vary with the income level of the area, the distance from the Negro ghetto, the type of housing, the ethnic make-up of the surrounding white community, and many other factors.

Kaplan, supra note 6, at 393. See text accoinpanying notes 18-25 supra.

124. See note 45 supra and accompanying text.
} 
point. ${ }^{125}$ There is no a priori reason to assume that the suburb's white residents will have a collective tipping point that corresponds to the percentage of the entire area's black population. ${ }^{126}$ In metropohtan areas with large percentages of blacks, the mirror target may be too high to deter tipping - a historically white suburb might tip at $20 \%$ even though the metropolitan area is $35 \%$ black. ${ }^{127} \mathrm{Or}$, in areas in which the inetropolitan black population is relatively small, the mirror target can be set at an entry level substantially below the tipping point. If the goal is set too high, so that it surpasses the tipping point, the progrann will not retain the desired number of whites. If the goal is set too low, so that it is beneath the tipping point, blacks are unnecessarily restricted, for the community would tolerate additional black entry without tipping. ${ }^{128}$ Mirror targets, therefore, are only tenuously connected to the objective of preventing tipping, because their connection to the coinmumity's tipping point is virtually random. Instead, mirror targets appear to reflect a judgment that it is equitable or desirable that a suburb contain no greater percentage of blacks than the metropohtan area. Apparently the percentage of black population in the metropolitan area establishes the ceiling on the "fair share" of blacks that suburban cominunities may be asked to accept.

Whether the method of computation is exact or inexact and whether the inpulses behind any given integration-mamtenance plan are grounded primarily on sociological or primarily on normative judgments about an ideal racial mix, all plans, by definition, attempt to achieve a racial mix other than that which the marketplace will produce. And further, whether intended solely to deter tipping or in part to effectuate a preconceived ideal racial mix, the chosen method of such plans is to circuinscribe black entry. ${ }^{129}$

\section{The Ulterior Interests: Utilitarianism and the Universalist} Ethic. To understand fully the governmental objectives underlying integration inamtenance, the immediate purpose of altering the racial mix by limiting black entry should be placed in the philosophical and jurisprudential context froin which that purpose is derived. Integration inaintenance reflects at least two classic strams of American legal and

125. Navasky writes, "Perhaps the resultant [tipping point] ratios will resemble [the mirror quota], but if so, this will be a coincidental rather than necessary reseinblance." Navasky, supra note 2 , at $47-48$.

126. See Goering, supra note 3, at 69-70.

127. See id.

128. See Schclling, supra note 3 , at 166.

129. Those plans that profess to do no more than encourage white entry inust, as a corollary, discourage black entry. 
social thought. The first, utilitarianism, is the belief that restrictions on individual freedom are permissible when necessary to achieve the greatest good for the greatest number of people. The second, the universahist ethic, is an assimilative ideal that holds that a country's public policy should achieve "balanced" or "proportional" racial and ethnic representation in all aspects of the nation's culture.

Utilitarian thouglt is not new in the context of racial policy. In Parent Association v. Ambach, ${ }^{130}$ the Court of Appeals for the Second Circuit was faced with a program that limited black enrollment in certain public schools by quotas designed to deter white flight from those schools, a plan analogous to integration maintenance: ${ }^{131}$

The constitutional issue thus posed is not unfamiliar in a democratic society. The greatest good for the greatest number is a concept deeply embedded in our history. It is ironic that it comes full circle in a case involving minority groups where the issue may be viewed as a conflict, not necessarily between the claims of whites and those of non-whites, but between the competing rights of non-whites themselves. May an individual non-white student be made to suffer exclusion in a community effort to prevent resegregation of the system? ${ }^{132}$

The court in Ambach answered its rhetorical question in the affirmative and in doing so explicitly subordinated the idea that individuals should not be treated differently on the basis of race to the idea that racially disparate treatinent is permissible if it is done for the "greater good"to avoid white flight and preserve a stable racial mix. ${ }^{133}$

The "greater good" as defined in Ambach evokes a strain of Ainerican legal thought, of which integration maintenance is a part, that provides that a balanced dispersal of blacks throughout all seginents of society is desirable for its own sake. Professor Mark Yudof describes this intellectual tradition as the "universalist ethic":

The cornerstone of the liberal, progressive thinking is what might be called a universalist ethic, the basic premise of which is that a stable, just society, without violence, alienation, and social discord, must be an integrated society. Segregation of the races in public institutions, employment, and housing will inevitably lead to conflict and the destruction of democratic values and institutions. In short, the goal is a shared culture in which all segments of the population participate. ${ }^{134}$

130. 598 F.2d 70 (2d Cir. 1979).

131. Id. at $710-12$.

132. Id. at 719.

133. See id. at $719-20$.

134. Yudof, Equal Educational Opportunity and the Courts, 51 TEX. L. Rev. 411, 457 (1973) (footnote omitted). As Yudof points out, the universalist ethic does not reflect reality. See also N. Glazer \& D. Moynihan, Beyond the Melting Pot (1963). 
The universalists are concerned not with the internal fairness of society's processes, but with the social consequences of these processes. $^{135}$ The universalist regards racial heterogeneity as inherently superior to racial homogeneity. To be just, society must be geographically integrated in fact, not simply void of discriminatory barriers to free geographic movement. ${ }^{136}$ Integration maintenance thus accepts as virtually self-evident the proposition that large concentrations of blacks in the suburbs are to be avoided and that government may intervene in housing markets on a racially selective basis to prevent such concentrations.

\section{The Countervailing Interests: The Impact on Personal Rights.}

To coinplete the description of the legal context within which the legality of integration inamtenance should be assessed, one inust examine the extent to which integration maintenance restricts the free exercise of personal rights. A natural consequence of the utilitarian jurisprudence that underlies integration maintenance is the tendency to undervalue the individual freedonis that minority-group inenibers are asked to sacrifice in the implementation of integration-mamtenance plans. If the goal is the greatest good for the greatest nunber, individual freedoms should be sacrificed by the few if the result is an enhancenient of good for the inany. Individuals within a racial group becoine fungible commodities that may legitimately be manipulated to achieve a desirable racial balance. Whiteness and blackness are the two characteristics that inexorably rise to prominence in the cominunity's implementation scheme; more personalized differences only get in the way.

Integration maintenance does not depend on the consent of blacks, individually or as a group. The governing bodies of predominantly white cominunities impose integration maintenance in order to prevent the cominunity froin becoming predominantly black. Blacks do not participate significantly in the political processes that produce integration-maintenance plans. ${ }^{137}$ No governing body of a traditionally all-

135. See N. GLAZER, supra note 60, at 48. (“' 'Opportunity' it seems is being redefined as 'result' "); Bell, Elthicity and Social Change, in N. Glazer \& D. MOYNIHAN, ETHNicity, THEORY AND EXPERIENCES 140, 147 (1975) ("The presumed failure of the idea of equality of opportunity has shifted the definition of that value to equality of result; and by fiat if necessary") (emphasis in original).

136. See Note, Ameliorative Racial Classifications Under the Equal Protection Clause, 1973 DUKE L.J. 1126, 1148-49; Note, Benign Steering, supra note 2, at 953-55.

137. It is clear that the black community is nowhere near a consensus regarding integration maintenance. In Chicago, for example, the local chapters of the Southern Christian Leadership Conference (SCLC) and the Natioual Association for the Advancenent of Colored People 
white suburb has ever adopted a program designed to ensure a racial population of $75 \%$ black and $25 \%$ white. It is safe to assume that the white representatives of predominantly white suburbs are not hikely ever to enact such an ordinance. A $75 \%$ black population is obviously not what "successfully integrated" means to such a governing body, though a $75 \%$ white population may be. ${ }^{138}$

The utilitarian thesis is inappropriate for integration maintenance because in all cases the group asked to bear the burden is predetermined and membership is inescapable. The inajority, defining the "greater good" in its own terms, dictates the burdens to be borne by the few. Integration maintenance is simply not on the same inoral footing as other race-conscious programs that claim an ameliorative purpose. ${ }^{39}$

A primary function of the fourteenth annendment is to remove racial issues from the transitory whims of majoritarian politics. ${ }^{140}$ If the meaning of the equal protection clause as it has evolved from Plessy $v$. Ferguson ${ }^{141}$ through Brown v. Board of Education, ${ }^{142}$ Bakke, and Fulli-

(NAACP) oppose such plans, but the national NAACP has apparently endorsed the concept. See Note, Benign Steering, supra note 2, at 939-40. The essential point, however, is that civil rights groups cannot and do not presume to act as a substitute for actual political participation by individual blacks. Concerning integration maintenance legislation, blacks are by definition the political "outs," yet they bear the burdens of the benign legislation enacted by the "ims."

138. See Note, Benign Steering, supra note 2, at 941: "[B]lacks and whites appear to have sharply differing notions as to what constitutes integration. To most blacks, an integrated community is approximately $50 \%$ black, but most whites consider a community to be integrated if there are merely a few black residents." Id. (citing Farley, Bianchi \& Colosanto, Barriers to the Racial Integration of Neighborhoods: The Detroit Case, 441 AnNals 97, 101 (1979)).

139. As John Hart Ely lias demonstrated, there is little reason to be suspicious of a raceconscious government program enacted by a white majority representative body that tends to disadvantage whites in favor of members of a black minority. Ely, supra note 60, at 735.

140. See, e.g., Hunter v. Erikson, 393 U.S. 385 (1969); Anderson v. Martin, 375 U.S. 399 (1964); Van Alstyne, supra note 60, at 783-92.

141. 163 U.S. 537 (1896).

142. 347 U.S. 483 (1954). If Brown left any doubt about the demise of the "separate-butequal" doctrine, this doubt evaporated in the wake of the swift series of decisions that followed in which the Court struck down race-conscious laws conceruing all aspects of American life. See, e.g. , Lee v. Washington, 390 U.S. 333 (1968) (segregation of jail inmates); Loving v. Virginia, 388 U.S. 1 (1967) (anti-1niscegenation laws); Anderson v. Martin, 375 U.S. 399 (1964) (requirement of racial designation of candidates on ballot); Johnson v. Virginia, 373 U.S. 61 (1963) (state judge's order to move to a section of a courtroom reserved for blacks); Turner v. City of Memphis, 369 U.S. 350 (1962) (segregation in airport restaurant); State Athletic Comm'n v. Dorsey, 359 U.S. 533 (1959) (segregation in athletic contests); New Orleans City Park Improvement Ass'n v. Detiege, 358 U.S. 54 (1958) (racial discrimination in public parks); Gayle v. Browder, 352 U.S. 903 (1956) (per curiam) (discrimination on public buses); Holmes v. City of Atlanta, 350 U.S. 879 (1955) (discrimination at mumcipal golf courses); Mayor of Baltimore v. Dawson, 350 U.S. 877 (1955) (discrimination in public bathhouses); Muir v. Louisville Park Theatrical Ass'n, 347 U.S. 971 (1954) (discrimination in park facilities leased from city). See also Van Alstyne, supra note 60, at 783. 
love is that minority rights may not be sacrificed even if the entrenched majority perceives that sacrifice to be for the greater good and if the clause's limitations on government activity are, like many of the core limitations of the Constitution, designed to insulate minorities without political power from the machinations of the political process, then the integration-mamtenance rationale fails because it supplies a utilitarian answer to an essentially non-utilitarian question. Although it is perfectly permissible for mdividuals of any race to believe as a matter of personal ideology that communities with black populations of approximately $30 \%$ enjoy an "ideal" racial mix, does the Constitution permit the government to embrace such racial distribution preferences? The constitutional issue thus posed is not whether the governmental decisionmaker has added his sums correctly im computing the greater good, but whether the color of skin is a legitimate predicate for the assignment of pluses and minuses.

\section{E. Ethnic Identity and Freedom of Choice.}

Because the color of a person's skin and the identity of one's parents are imvoluntary and immutable characteristics, there is a tendency to regard ethnic and racial identity as forever determined at birth. Government programs that are overtly conscious of racial or ethnic identity assume that racial and ethric identities are not matters of imdividual choice or allegiance, but rather matters of governmental definition in which the defining characteristics are predetermined and immutable. Persons are not free simply to declare themselves black and thus ehgible for the ten percent minority busmess enterprise provision. ${ }^{143}$ When government uses race and ethnicity as bases for allocating burdens and benefits, it is not for individuals but for government to say who and what they are.

In the last two decades, however, a countervailing judgment that ethnic identity is and should be a matter of choice has arisen in American culture. In normative terms, the principle is that every citizen should be free to choose the extent to which he wishes to emphasize or deemphasize his own ethnicity. In legal terms, the primciple is one of free association: a virtually infinite spectrum of individual preference for ethnic association exists, and every such gradation of choice is entitled to respect.

Recent sociological literature emphasizes choice as a primiary determinant of ethnic identity. Professor Orlando Patterson states that

143. See text accompanying notes 67-68 supra. Presumably the requirement of "satisfactory assurance" extends to determining inclusion among the listed minority groups. 
individuals can choose the sociological and psychological significance they attribute to a given trait and therefore they can choose their own degree of ethnic allegiance. 144 Patterson defines "ethnicity" as a social condition in which certain individuals "choose to einphasize as their most meaningful basis of primary, extrafamilial identity certain assumed cultural, national, or somatic traits."145

Daniel Patrick Moynihan and Nathan Glazer have identified a resurgence of ethnic identification in American he. In Beyond the Melting Pot, ${ }^{146}$ they found that the prevailing inyth of cultural assimilation of ethnic groups into a common "American" identity, in which the significance of racial and ethnic lines tends to disappear, does not reflect reality. ${ }^{147}$ On the contrary, strong bonds of ethnic and racial allegiance have emerged to hinider the assimilation process. ${ }^{148}$

The recent resurgence of ethnic identity represents the aggregate of conscious individual strategic choices. Professor Daniel Bell describes the phenoinenon as a dynamic pattern of individual decisions to emphasize or deemphasize ethnic group membership based on tactical considerations of gaimmg power and privilege. ${ }^{149}$ Ethnic identity is not a fixed and essential part of the psyche; it is a choice imfluenced by the "political and economic circumstances" of the individual. ${ }^{150}$

The conflict between assimilation and resurgence of ethnic identity has been particularly strong for American blacks. ${ }^{151}$ Since the 1960s, individual blacks frequently have chosen to einphasize their group identity as a means of achieving greater political and economic power. ${ }^{152}$ Increased black ethnic identity as a political phenomenon repeats a familiar American pattern. Particularly in the nation's older

144. See Patterson, Context and Choice in Ethnic Allegiance: $A$ Theoretical Framework and Caribbean Case Study, in N. Glazer \& D. Moynlhan, Ethnicity, Theory and Experience 305, 306-07 (1975).

145. Id. 308.

146. N. Glazer \& D. Moynihan, Beyond the Melting Pot (1963).

147. See id. 5.

148. Id 16. ("Americans becoine more 'American' and less ethnic all the time. But in the course of participating in this process they may also-sinultaneously-become more 'ethnic' ").

149. [E]thnicity, in this context, is not understood as a primordial phenomenon in which deeply held identities have to reemerge, but as a strategic choice by individuals who, in other circumstances, would choose other group memberships as a means of gaining some power and privilege. In short, it is the salience not the persona which has to be the axial line for explanation. And because salience may be the decisive variable, the attachment to ethnicity may flush or fade very quickly depending on pohitical and economic circumstances.

Bell, supra note 135, at 171 (emphasis in original).

150. $I d$.

151. See N. Glazer \& D. MoYNihan, supra note 146, at 16.

152. See Parsons, Change of Ethnicity, in N. Glazer \& D. MOYnihan, EthNicity, THeory AND EXPERIENCE 53, 76-79 (1975). 
cities, it has never been thought wrong or unusual for persons to emphasize their own ethnicity to gain political or social advantage. ${ }^{153}$ Similarly, although discrimination against blacks undoubtedly accounts for inucl of their concentration and collective isolation in urban areas, it is impossible to eliminate choice of ethnic association as a reason for the concentration. ${ }^{154}$ In short, Americans often clioose to group themselves on an ethnic basis because they perceive that identification as economically, politically, or culturally advantageous.

Integration maintenance seeks to prevent concentrations of blacks in the suburbs. If the integration-inamtenance concept is projected to its logical conclusion, blacks would be diffused evenly across the inetropolitan landscape. With that geographic dispersal, black political power would be diluted, 155 and the strength of the black economic political, religious, and cultural institutions that facilitate cohesive group identity and consciousness would be diminished. ${ }^{156}$

The lexicon of integration maintenance reveals the concept's imherent cultural condescension: concentrations of blacks in suburbs are almost always called ghettos. ${ }^{157}$ The condescension is not pernicious but unintentional; it arises from "an understandable tendency to assume that the ghetto pattern of existence [is] the natural mode of living for urban blacks." 158 This perception is reinforced when the black suburb is inerely a plrysical extension of a truly urban glietto, ${ }^{159}$ even though sociologists classify a substantial percentage of the black population in the United States as middle class. ${ }^{160}$ It is racial stereotyping to assume that a middle-class suburban community may be labeled a "ghetto" because over half of its residents are blacks.

153. Kilson, Blacks and Neo-Ethnicity in America, in N. GLAZER \& D. MOYNIHAN, ETHNICITY, THEORY AND EXPERIENCE 236, 238-40 (1975).

154. N. GLAZER, supra note 60 , at 153 ("Whatever the conclusion as to the weight of economic factors alone, however, it is impossible to separate from the remaining part of the concentration [of blacks] to be explained the part owing to discrimination and the part owing to culture, taste, wishes, preferences").

155. Kaplan, supra note 6, at 397-98 ("The practical fact of politics . . is that only where a minority group, especially a disorganized one, is concentrated, can it enjoy the benefits of political organization").

156. Id. 398. Insofar as the universalist ethic would mandate dispersal of blacks, it inevitably would undercut the cohesiveness of black culture and the rich contribution of the culture to American life. Id.

157. See, e.g., Note, Benign Steering, supra note 2, at 941-44.

158. Parsons, supra note 152, at 79.

159. The geographic proximity of a changing racial neighborhood to a neighborhood that is already identifiably black appears to contribute to the chances of precipitous white flight. See Goering, supra note 3 , at 74.

160. Parsons, supra note 152 , at $77-78$ (listing estimates of middle-class blacks froin $52 \%$ to $35 \%$ of the black population). 
It may be assumed that no rational person seeks out dilapidated housing, poor neighborhood schools, high crime, and substandard police and fire protection. It inay not be assuined, however, that a rational person does not want to live in a black neighborhood. Government inust not equate the two. Individual blacks with the means to move to the suburbs may or may not wish to live in neighborhoods in which there has been substantial black entry. Unfortunately, no individual black can be sure that his entry into a white neighborhood, when coinbined witl the entry of other blacks, will not cause an exodus of whites. Surely, however, individual blacks deserve the freedom to inake decisions of affiliation. Integration maintenance presumes that restrictions on choices for blacks are permissible because otherwise whites will exercise their own choices and move away. Black political and cultural cohesiveness is given no weight in the balance, even though the preservation of white cohesiveness and majority status is the practical, and arguably deliberate, consequence of the balance that is struck.

\section{F. Choice and the Right to Travel.}

The premise that government has a right to intervene in the geographic distribution of the population cannot be reconciled with the right to travel-a right that has long been part of the nation's culture and that has recently been elevated to constitutional status. American history is largely a history of migrations. Long before the Supreme Court recognized the freedom to travel as a constitutional right, Americans assumed that citizenship carried with it the privilege to move about the country unfettered by restrictive governmental regulation. ${ }^{161}$

Article four of the Articles of Confederation explicitly guaranteed the right to travel froin state to state, ${ }^{162}$ but neither the Constitution nor any subsequent ainendment mentions this right. Nevertheless, as early as 1823 judicial pronounceinents recognized the right to travel as imphicit in the constitutional structure. ${ }^{163}$ In 1849 Chief Justice Taney

161. Indeed, one of the oldest and most well-entrenched explanations of the American historical experience interprets American culture in terms of the freedom to travel, the always available option to "light out for the West" like Huck Finn. The "Froutier Hypothesis" of Frederick Jackson Turner is perhaps the best known statement of this idea. See, e.g., H. SMith, ViRGIN LAND 250 (1950). DeTocqueville also emphasized the significance of free mobility in American hife. See A. DeTocqueville, Democracy in America 300 (Colonial Press rev. ed. 1900).

162. U.S. ARTS. OF CONFED. art. 4 ("[T] he people of each State shall have free ingress and regress to and from any other State....").

163. In Corfield $v$. Coryell Justice Washington histed as one of the privileges and immunities of citizenship, "[t]lie right of a citizen of one state to pass through, or to reside in any other state." 6 F. Cas. 546, 552 (C.C.E.D. Pa. 1823) (No. 3230). 
wrote in dissent in the Passenger Cases: 164

For all the great purposes for which the Federal government was formed, we are one people, with one common country. We are all citizens of the Umited States; and, as members of the same community, must have the right to pass and repass through every part of it without interruption, as freely as in our own States. ${ }^{165}$

During this century the right to travel has ennerged as a fundainental constitutional right. In United States $v$. Guest ${ }^{166}$ Justice Stewart observed that "freedoin to travel throughout the United States has long been recognized as a basic right under the Constitution," 167 and in Shapiro v. Thompson ${ }^{168}$ the Supreme Court stated "that the nature of our Federal Union and our constitutional concepts of personal liberty unite to require that all citizens be free to travel throughout the length and breadth of our land uninhibited by statutes, rules or regulations which unreasonably burden or restrict this movement." 169

Prior to the Civil War, of course, blacks who were held as slaves did not enjoy the right to travel. In Dred Scott $v$. Sandford, ${ }^{170}$ Justice Taney, who had declared in ringing teruns the fundamental nature of the right to travel, wrote for the Supreme Court that the slave Dred Scott did not obtam emancipation for himself or his family by traveling from the slave state of Missouri to the free state of Illinois. ${ }^{171}$ Blacks, wrote Taney, "had for more than a century before [the Declaration of Independence and the adoption of the Constitution] been regarded as

164. 48 U.S. (7 How.) 282 (1849).

165. Id. at 492 (Taney, C.J., dissenting).

166. 383 U.S. 745 (1966).

167. Id. at 758 .

168. 394 U.S. 618 (1969).

169. Id. at 629. Shapiro struck down durational residency requirements for eligibility for welfare assistance. In the aftermath of Shapiro many durational residency requirements have been overturned by the Supreme Court. See, e.g., Meinorial Hosp. v. Maricopa County, 415 U.S. 250 (1974) (voidmg a one-year residency requirenent for receipt of free nonemergency medical care for indigents); Dunn v. Blumstem, 405 U.S. 330 (1972) (imvalidating a one-year residency requirement for voting eligibility); Wyman v. Bowens, 397 U.S. 49 (1970), aff g per curiam, 304 F. Supp. 717 (N.D.N.Y. 1969) (striking down a prohibition on the welfare eligibility of persons who came into the state solely to obtain welfare assistance).

The Court has upheld against right to travel challenges residency requirements for municipal employees, McCarthy v. Philadelphia Civil Serv. Comm'n, 424 U.S. 645 (1976); durational requirements for divorce, Sosna v. Iowa, 419 U.S. 393 (1975); residency and durational requirements for membership in the bar, Brown v. Supreine Court, 414 U.S. 1034, affg mem., 359 F. Supp. 549 (E.D. Va. 1973); and residency requirements for lower tuition at state universities, Starns v. Malkerson, 401 U.S. 985 (1971), affg mem., 326 F. Supp. 234 (D. Minn. 1970). In Village of Belle Terre v. Boraas, 416 U.S. 1 (1974), the Supreme Court upheld a zonimg ordinance that permitted only single family housing and limited occupancy of such housing to related persons or less than three unrelated persons.

170. 60 U.S. (19 How.) 393 (1856).

171. Id. at 399. 
beings of an inferior order, and altogether unfit to associate with the white race, either in social or political relations; and so far inferior, that they had no riglits which the white inan was bound to respect."172 Free blacks froin northern states also were subject to travel restrictions prior to the Civil War. For example, several slaveliolding states adopted legislation to preclude the entry of free blacks in order to deter slave uprisings. ${ }^{173}$

In light of this unfortunate legacy it is difficult to defend any government program that inhibits the free exercise of the right of blacks to travel, even if the action discourages black entry obliquely rather than directly . ${ }^{174}$ A black does not have the same right to travel as a white if an ordinance prohibits the sale of property on a certain block to blacks because blacks constitute $30 \%$ of the residents. Although the black nnay still be permitted to purchase in nearby villages, his right to travel is abrogated because the essence of the freedoin to travel is choice.

In housing, the right to travel unshackled by racial restrictions is coupled with the traditional notion of Anglo-American law that every parcel of property is unique. ${ }^{175}$ Specific enforceinent of a land sale contract is permitted because the law assunes that no other piece of real estate is an adequate substitute for the real estate described in the contract. ${ }^{176}$ Any restriction on the right to live where one wishes is a substantial one.

Even with less rigid forms of integration inaintenance, prospective sales to blacks are discouraged by the chilling effect sales to whites are likely to have on the local real estate inarket. The tacit inessage underlying the encourageinent of white entry is the discourageinent of black entry. Limitation of black entry and avoidance of the tipping point are the explicit predicates of integration inaintenance. Thus, any commu-

172. Id. at 407.

173. See generally Elkison v. Deliesseline, 8 F. Cas. 493 (C.C.D.S.C. 1823) (No. 4366); 2 Op. Att'y Gen. 426 (1831); 1 Op. Att'y Gen. 659 (1824); 1 C. WARren, The SuPreme Court iN UNITED STATES History 624-27 (rev. ed. 1947).

174. In Memorial Hosp. v. Maricopa County, 415 U.S. 250 (1974), the Court reexamined Shapiro v. Thompson, 394 U.S. 618 (1969), and made clear that the core of the right to travel is a proscription of governmental activity that burdens or penalizes "the right to migrate "witl intent to settle and abide." " 415 U.S. at 255 (quoting Sliapiro v. Tliompson, 394 U.S. at 629). The Court stated that the right to travel was not unlikc the Biblical admonition in Levilicus 24:22: "Ye shall lave one inanner of law, as well for the stranger as for one of your own country.'" 415 U.S. at 261. Although the precise parameters of the Maricopa penalty analysis are difficult to articulate, the Court made it plain that once the plaimtiff sliows a tendency to "penalize the exercise of the right to travel," it is not necessary to show actual deterrence of migration to prove a constitutional violation. Id. at 257 (emphasis in original).

175. See generally 5A CORBIN ON CONTRACTS $\$ 1143$ (1964); 11 WILLISTON ON CONTRACTS § 1418A (3d ed. 1964).

176. See, e.g., 1 Pomeroy, A Treatise on Equity Jurisprudence $\$ 221$ (b) (4th ed. 1918). 
mity adopting a plan requiring the encouragement of white, but not black, entry must know that the end result of its steering efforts will almost certainly be the discouragement of nonwhite racial groups.

Having relegated nonwhite groups to the limbo of official non-encouragement, the community should be held accountable if private real estate agents give exclusionary meaning to such comparative shades of nonenthusiasm. The prospective black entrant is denied the right to migrate to the specific block he prefers and the freedom to select the house he desires to buy. ${ }^{177}$ Because he is black, and because the municipality beheves that whites may leave if more blacks enter the commumity, lie is denied the freedoms to move and to purcliase that whites enjoy.

The right to travel is not absolute; it is subject to reasonable restrictions. ${ }^{178}$ For example, local communities exercismg their growthmanagement function may discourage immigration to limit tleir overall growth, or they may seek to mamtam their rural or residential cliaracters by using zoning and land use restrictions. ${ }^{179}$ Similarly, suburbs may use race-neutral zoning laws to restrict the construction of multi-

177. See Kaplan, supra note 6, at 391. From the perspective of the potential black entrant, Professor Kaplan notes, the positive value of proinoting integration inay be subordinate to the economic advantages of procuring housing in a specific area of a community. Thus, to the integration inaintenance proponent, an individual black might reply:

I understand that my hiving here may destroy the benefits of integration for me and nyy neighbors and hence, were integration the only reason for my wishing to live here, I would not ask for admittance. The fact is, however, that this housing at its price is vastly superior in terns of freedom from rat-infestation, plumbing facilities, light, air, space and many other things to the housing I am now in. Though I inight accept being prevented from destroying the integration which I sought, it is inuch harder for me to take that view when the right I am seeking is to live in this building, integrated or not. When you deny me housing because I ain a Negro, it is sinall consolation to ine to be told that you are fighting agamst the very evil which is a basic cause of my problem. Your solution takes a long timie and I need decent housing now.

Id. It is also worth noting that although the right to travel cases have involved interstate migration, see, e.g., Evansville-Vanderburg Airport Auth. Dist. v. Delta Airlines, Inc., 405 U.S. 707 (1972), in the housing context there should be hittle doubt that the right is inplicated even when the move entails restrictions only on free intrastate migration. As is suggested by Chief Justice Taney's statement in the Passenger Cases that the interstate right to travel is as fundamental as the right to travel freely "in our own states," 42 U.S. (17 How.) 283, 492 (1849) (Taney, C.J., dissenting), movement within a state is so fundamental a right that its existence has never been seriously questioned. See D. Godschalk, D. Brower, L. McBennett, B. Vestal \& D. Herr, ConstiTUTIONAL Issues OF GROWTH MANAGEMENT 96 (rev. ed. 1979). Further, both Shapiro v. Thompson and Memorial Hosp. v. Maricopa County emphasize that the primary focus of the right to travel is to preserve the right to freely "niigrate with intent to settle and abide." Memorial Hosp. v. Maricopa County, 415 U.S. 250, 255 (1974); Shapiro v. Thompson, 394 U.S. 618, 629 (1969).

178. See, e.g., Shapiro v. Thoinpson, 394 U.S. 618, 629 (1969).

179. See, e.g., Village of Belle Terre v. Boraas, 416 U.S. I (1974); Ybarra v. City of Los Altos Hills, 503 F.2d 250 (9th Cir. 1974). 
ple-unit low-incoine housing. ${ }^{180}$ Integration maintenance, however, appears to penalize migration in a manner that is per se unreasonable. Integration maintenance does not manage growth or land use; it does not restrict the number of persons who may move into an area; it restricts the type of persons who may enter.

Like most constitutional freedoms, the right to travel not only preserves individual prerogative, but also establishes the degree of government intervention that the Constitution will tolerate. Viewed as a directive that defines the proper stance of local governments on population migrations, the right to travel prohibits the deterrence of the entry of whole classes of persons. With the unique exception of reservations established for American Indians, ${ }^{181}$ the nation has consistently refused to permit subdivision of the country's landscape into political units forinally identified in racial or ethnic terms. Professor Nathan Glazer has identified the nation's refusal to allow any ethnic group to establish an independent polity in the United States as one of the major decisions in America's historical consciousness. ${ }^{182}$ Unlike many otler multi-ethnic societies, such as the Soviet Union, the United States public authority has never provided ethnic groups with an autonomous region of sovereignty. ${ }^{183}$ No states, cities, or counties have ever been reserved to the exclusive use of any ethnic group. ${ }^{184}$ No matter how ubiquitous racism or nativisin has been at any time in our history, local governments have never been allowed to organize themselves as exclusive havens for any race. ${ }^{185}$

The case of Edwards v. California ${ }^{186}$ provides a useful analogy to integration inaintenance. In Edwards, the Supreme Court invalidated a California statute making it a misdemeanor to bring into or to assist in brimging into California "any indigent person who is not a resident of the State, knowing him to be an indigent person." 187 The statute was the product of many of the same impulses that lead to integration maintenance. Popularly called the "Okie law," the California statute

180. See, e.g., Village of Arlington Heights v. Metropolitan Hous. Dev. Corp., 429 U.S. 252 (1977); Joseph Skillken \& Co. v. City of Toledo, 528 F.2d 867 (6th Cir. 1975); Mahaley v. Cuyahoga Metropolitan Hous. Auth., 500 F.2d 1087 (6th Cir. 1974).

181. See L. Tribe, American Constitutional Law § 16-14 (1978).

182. See N. GLAZER, The Emergence of an American Ethnic Pattern, in AFFIRMATIVE DisCRIMINATION 5 (1975).

183. Id. 22-25.

184. See id.

185. Id.

186. 314 U.S. 160 (1941).

187. Id. at 171 . 
was enacted to stem the tide of dust-bowl migration. ${ }^{188}$ Like suburbanites who argue that black entry will cause their neighborhoods to deteriorate, California argued that "the huge influx of migrants into California in recent years has resulted in problems of health, morals, and especially finance, the proportions of which are staggering." 189

The Court recognized California's dilemma, but nonetlieless struck down the statute, statimg that the Constitution prohibits "attempts on the part of any single State to isolate itself from difficulties common to all of them by restraining the transportation of persons and property across its borders." 190 The Court noted the strong temptation for a state to attempt to "gain a momentary respite from the pressure of events by the simple expedient of shutting its gates to the outside world," 191 but declared that " $[t]$ he Constitution was framed under the dominion of a political philosophy less parochial in range." "192

The self-interest of white residents wlo seek to turn back the migration of blacks to the suburbs in the 1980s is no less parochial than was the self-imterest of Californians who sought to slut the gates to migrant farmers in the 1930s. Whether the ill effects of increasing black populations in the suburbs are real or imagined, the Constitution does not permit commumities to indulge those fears by creating racial impediments to travel $\mathrm{m}$ an attempt to insulate themselves from such effects.

In effect $E d w a r d s$ denies local governments the easiest alternative in addressing the perceived social and economic ills accompanymg the entry of persons who are regarded as part of a "class of carriers" of such ills. However attractive it nıay seen to place race-conscious guards at the gates to the suburbs, the Constitution precludes this option. It is an unhappy fact of American experience that when blacks enter a neighborhood, whites sometimes leave in fear. The quick remedy to this problem is to mampulate black entry, but this is the one remedy that $E d w a r d s$ forbids.

\section{G. Bakke and Fullilove Applied.}

Given the substantial impact that integration-maintenance plans have on individual rights, the dispositive issue in assessing the constitutionality of such plans is whether the government's objectives are suffi-

188. See G. Gunther, Constitutional Law, Cases and Materials 302-03 (10th ed. 1980).

189. 314 U.S. at 173.

190. Id.

191. Id.

192. Id. at 173-74 (quoting Baldwin v. Seelig, 294 U.S. 511,523 (1935)). 
ciently important to justify their concomitant restrictions on personal freedoms. Bakke ${ }^{193}$ and Fullilove ${ }^{194}$ may be interpreted as absolutely banning race-conscious plans that inhibit the exercise of minority rights. ${ }^{195}$ If this interpretation is accepted, it is unnecessary to weigh the importance of the government's objectives. If, as Justice Marshall intimated in Fullilove, programs that ask blacks to bear the brunt of the social cost or tend to act as a ceiling on minority opportunity are "invalid without nore,"196 the strength of the goals pursued by integration maintenance is irrelevant.

But assuming arguendo that the importance of the government's objectives is sufficiently substantial to overcome the protection of minority rights, a court must still first weigh the constitutionahity of the goals underlying integration maintenance. ${ }^{197}$ Two issues pertain to this examination: first, the legitimacy of predicating governmental policy on the avoidance of white flight; and second, the legitimacy of pursuing an "ideal" racial balance as an end in itself.

1. Predicating Policy on Avoiding White Flight. A major reason for rejectimg the utilitarian position that integration maintenance is justified by the "greater good" of avoiding white flight ${ }^{198}$ is that theoretically benign political calculations of the greater good based on race have an unfortunate history in America. In 1917, long before Brown v. Board of Education, ${ }^{199}$ the Supreme Court in Buchanan v. Warley 200 struck down a municipal ordinance enacted by the city of Louisville, Kentucky. The ordmance was strikingly similar to that proposed by Oak Park in 1974.201 The Louisville ordinance made it unlawful

for any colored person to move into and occupy as a residence, place of abode, or to establish and maintain as a place of public assembly any house upon any block upon which a greater number of houses are oceupied as residences, places of abode, or places of public assembly by white people than are occupied as residences, places of abode, or places of public asseinbly by colored people. ${ }^{202}$

193. Regents of the Univ. of Cal. v. Bakke, 438 U.S. 265 (1978). See text accompanying notes 61-66 supra.

194. Fullilove v. Klutznick, 448 U.S. 448 (1980). See text accoinpanying notes 67-72 supra.

195. See text accoinpanying notes 82-88 supra.

196. Fullilove v. Klutznick, 448 U.S. 448,518 (1980) (quoting Regents of the Univ. of Cal. v. Bakke, 438 U.S. 265, 358 (1978) (Brennan, Marshall, White, \& Blackmun, JJ.)).

197. See note 5 supra and accompanying text.

198. See notes 130-36 supra and accompanying text.

199. 347 U.S. 483 (1954).

200. 245 U.S. 60 (1917).

201. See notes $40-43$ supra and accompanying text.

202. 245 U.S. at $70-71$. 
The city openly declared its motives for adopting the ordinance, which were probably generally regarded as bemign in 1917: "to promote the pubhic peace by preventing racial conflicts; . . . to maintain racial purity; [to prevent] the deterioration of property owned and occupied by white people, which deterioration, it is contended, is sure to follow the occupancy of adjacent premises by persons of color."203 The title of the ordinance stated that its objective was "to prevent conflict and ill-feeling between the white and colored races in the City of Louisville, and to preserve the public peace . . ."204 Indeed, the ordinance was adopted for inany of the same inotives as was the statute in Plessy $v$. Ferguson, which required separate passenger cars for black and white riders on trains. ${ }^{205}$ The majority in Plessy had characterized the "separate but equal" statute as "enacted in good faith for the proinotion of the public good, and not for the annoyance or oppression of a particular class."206 Although the Supreme Court accepted Louisville's assertion that the ordinance was desirable in promoting public peace and preventing racial conflicts, the Court struck down the ordinance, holding that such aims "cannot be accoinplished by laws or ordinances which deny rights created or protected by the Federal Constitution."207

Modern integration-maintenance plans can be distinguished from the Louisville ordinance struck down im Buchanan. Although current plans may superficially reseinble the Louisville ordinance, the representatives of suburban communities who adopt sucls plans in 1981 do so not to keep the races separate, but to keep them together. Nevertheless, integration-maintenance plans rest on an uneasy juxtaposition of conflicting inotives. They arise in suburbs containing white families whose individual tipping points converge to form a community tipping point-the point at which the community's collective racial tolerance gives way to its collective racial prejudice and fear. The constitutional question posed by the juxtaposition is whether the racial prejudices and fears that nndemably contribute substantially to white flight should be attributed to the governing body that enacts an integration-inaintenance plan, even if that body is itself motivated only by racial tolerance.

The question can be illustrated by liypothesizing two suburbs that enact identical integration-maintenance plans. One suburb is a longestablished town on the outskirts of Boston that still makes all its major

203. Id at $73-74$.

204. Id at 70 .

205. Plessy v. Ferguson, 163 U.S. 537, 540 (1896).

206. Id. at 550 .

207. 245 U.S. at 91. 
governmental decisions in town meetimgs. The second suburb employs a nodern representative form of government such as a city council. The first commumity convenes a meeting to discuss the "problein" of incipient black entry into the town. After a large number of residents say they will leave if black entry exceeds $25 \%$, the town adopts an integration-inaintenance ordinance, with two-thirds of the town's residents votimg to approve it. The ordinance requires brokers to discourage black entry once such entry exceeds $25 \%$ of the population.

If we were to poll the residents of the town to discover their motives for approving the plan, the social-science evidence previously discussed indicates that there would probably be a wide variety of responses. ${ }^{208}$ Soine residents were probably motivated purely by racial animus ${ }^{209}$ - soine white families are unwilling to live on the same block with a black family even if by all objective indicia there is no danger that the entry of one black family will have any effect whatsoever on the safety or prosperity of the neighborhood. ${ }^{210}$ As expressed in Trinity Episcopal School Corp. v. Romney, ${ }^{211}$ "[i]]n large ineasure, the tipping point is a subjective and prejudicial reaction of whites to mimority group encroachment." 212 Those residents inotivated by such separatist notions would be echoimg the rationale advanced by Louisville to defend its ordinance in 1917, but in language less offensive to the contemporary ear.

Although blind prejudice would motivate soine of the residents, the sociological data indicate that most residents would probably explain their action in less emotional terms, professing to be relatively free froin racial prejudice against blacks. ${ }^{213}$ Instead they would explam their vote as inotivated by fear of the imminent deterioration of their neighborhood if black entry is not controlled.214 The residents in this category would fear a decline in property values, an increase in crime and vandalism, and an erosion of the quality of neighborhood schools and essential government services. ${ }^{215}$

208. See Goering, supra note 3, at 70-77.

209. See Frey, supra note 3, at 443-44; Goering, supra note 3, at 75-76; Note, Benign Steering, supra note 2, at $941-42$.

210. See Goering, supra note 3, at 75-76; Navasky, supra note 2, at 32 .

211. 387 F. Supp. 1044 (S.D.N.Y. 1974), affd in part and rev'd in part, $523 \mathrm{~F} .2 \mathrm{~d} 88$ (2d Cir. 1975).

212. 387 F. Supp. at 1072.

213. See, e.g., Frey, supra note 3, at 427-29, 443-44; Goering, supra note 3, at 70-77; Note, Benign Steering, supra note 2, at 941 (citing N.Y. Times, Feb. 26, 1978, § 1, at 28, col. 2, which stated that in a 1978 survey, two-thirds of the whites surveyed stated they would not mind if a black family of similar status moved in next door).

214. See Goering, supra note 3, at 70-77.

215. $I d$. 
The ordimance enacted by such a town meeting would be plainly unconstitutional even though actual racial animosity may have accounted for only a small percentage of the votes. The myriad cultural and economic forces present at the town meeting were distilled into an overtly racial solution. It is irrelevant that in functioning as social planners the town's citizenry may arguably have acted rationally; it is enough that they acted racially-that they proceeded on the assumption that an increased black population would result in increased social and economic probleins.

Although Bakke indicates that the implication of inferiority is not always present when race is used to promote pluralism in education, the town's action sinply carmot escape the implication that the town regards blacks as inferior-that the town sees their concentrated presence $m$ the community as inevitably lowering the quality of life. ${ }^{216}$ The town's plan excludes an entire racial group froin the community on the assumption that economic, social, and educational decline inevitably accompany the entrance of blacks.

An identical integration-maintenance statute enacted by a nearby town with a representative form of government would also be unconstitutional. The political, social, and economic forces are similar in botlr communities. The immediate purpose of the ordinances is also identical: to restram mimority entry and to prevent the conmunity from tipping from predominantly white to predominantly black. The only difference is that in the representative body there may exist a consensus of ulterior altruistic purpose. The existence of that benign intent cannot be of constitutional significance, lowever, because the actions of the representative body cannot rise above tlie conimumity's fears and prejudices to which the representatives have surrendered.

If government programs are not racially explicit, the benign intent of the village council is a defense to a charge of a constitutional violation, and the burden is on the plaintiff to prove the existence of invidi-

216. See Rice, The Legality of De Facto Segregation, 10 CATH. LAw. 309, 320 (1964). In Trinity Episcopal School Corp. v. Romney, 387 F. Supp. 1044 (S.D.N.Y. 1974), rev'd on other grounds, 523 F.2d 88 (2d Cir. 1975), the court condemned such thinking in the context of assumptions about persons in lower economic classes:

We cannot subscribe to what we regard as an unteuable position advanced by plaintiff: they have associated the undesirable behavior of individuals with a broad economic class and claim that the expanding presence of that class is undesirable and a cause of tipping. We declare no meaningful proof exists im the trial record that the preseuce of that class is per se a cause of neighborhood deterioration.

387 F. Supp. at 1073 (emphasis in origimal). 
ous motive. ${ }^{217}$ In programs that are overtly race-conscious and tend to restrict nimority opportunity, the burden of proof is reversed. ${ }^{218}$ Integration mamtenance is overtly race-conscious, and so the burden is on the community to prove the program's absence of illegal purpose. 219

The Supreme Court has frequently acknowledged the difficulty of attemptimg to assess the motives of an entire legislative body.220 Many disparate motives are likely to exist among the representatives of a community adopting an integration-maintenance plan-some meinbers may vote for such plans out of undiluted racial hatred and others out of unadulterated good faith. But performing the difficult task of discerning the dommant legislative purpose is unnecessary in evaluating integration maintenance; such plans openly profess the constitutionally fatal contamination of altruism by racial fear. Because all integrationmanitenance plans have the undisguised purpose of limiting black entry to keep the black population below the point at which whites will leave, it makes no difference whether or not the majority of representatives voting for the plan harbors personal prejudice. Whatever the heartfelt purposes of the representatives, the community's governing body has spoken as the voice of the cominunity and has announced to its mostly white constituency: because your collective tipping points are of sufficient intensity that you threaten to exit, turning your community from predommantly white to predommantly black, we have enacted steps to restrain black entry to your collective tolerance limit.

A series of Supreme Court decisions holding that mere community opposition cannot repress the imperatives of the equal protection clause establishes the primciple that the good faith of community leaders is constitutionally irrelevant if those leaders accomodate community opposition to black entry. In Brown $I I,{ }^{221}$ the decision implementing the school desegregation cases of 1954, the Court declared that "the vitality

217. See, e.g., City of Mobile v. Bolden, 446 U.S. 55 (1980); Personnel Adm'r v. Feeney, 442 U.S. 256 (1979); Village of Arlington Heights v. Metropolitan Hous. Dev. Corp., 429 U.S. 252 (1977); Washimgton v. Davis, 426 U.S. 229 (1976).

218. See Fullilove v. Klutznick, 448 U.S. 448, $472-73$ (1980) (Burger, C.J.); id. at 495-96 (Powell, J., concurring); id. at 517-19 (Marshall, J., concurring); Regents of the Univ. of Cal. v. Bakke, 438 U.S. 265, 299 (1978).

219. Justice Powell wrote in Fullilove that "any official action that treats a person differently on account of his race or ethnic origin is presumptively invalid." Fullilove v. Klutznick, 448 U.S. 448,496 n.1 (1980) (citing the dissenting opinion of Justice Stewart, 448 U.S. at 523). However, Powell wrote, "in narrowly defined circuinstances, that presumption may be rebutted." Id. at 496 n.l. The practical effect of the Court's formulations in Bakke and Fullilove, then, is to shift the burden of proof to the government to defeat the presumptive illegality that automatically attaches to any explicitly race-conscious program. See notes 69-88 supra and accompanying text.

220. Compare Palmer v. Thompson, 403 U.S. 217 (1971) with Gomillion v. Lightfoot, 364 U.S. 339 (1960).

221. Brown v. Board of Educ., 349 U.S. 294 (1955). 
of [the] constitutional principles [set forth in Brown $I$ ] cannot be allowed to yield simply because of disagreement with them."222 In Monroe v. Board of Commissioners ${ }^{223}$ the Court reaffirmed this inandate by striking down a "free-transfer" plan used to desegregate the public scliools in Jackson, Tennessee, because the principal effect of the plan was to retaim racially identifiable schools rather than to dismantle the dual school system.224 Rejecting the school authorities' argument that "without the transfer option it is apprehended that white students will flee the school system altogether," 225 the Court ordered the school board to achieve a nonracial, nondiscriminatory systein and to ignore the prospect of community opposition. Several years later, in United States v. Scotland Neck Board of Education, 226 the Court invalidated the establishment of a new school district even though the school officials argued that the new district was necessary to avoid tlie exit of white students froin the system into private schools. The Court declared that white flight is not a justification for failing to uproot a racially discriminatory school system. ${ }^{227}$

Although the holdings in Brown II, Monroe, and Scotland Neck are clear, some lower courts have attempted to distinguish the accommodation of community opposition in those cases from the type of accoinmodation that occurs when government bodies undertake programs to retard white flight. 228 In Otero v. New York City Housing Authority, ${ }^{229}$ the housing authority liad decided not to adhere to one of its own administrative regulations. This regulation provided that first priority for occupancy in a public housing project in New York's lower east side would go to present and former occupants of the urban renewal site upon which the project was built, a category of persons consisting mainly of non-whites. ${ }^{230}$ The housing authority argued that the effect of "adherence to its regulation would be to create a non-white pocket ghetto that would operate as a racial tipping factor causing

222. Id. at 300 .

223. 391 U.S. 450 (1968).

224. Id. at $458-59$.

225. Id. at 459 .

226. 407 U.S. 484 (1972).

227. Id. at 485,491 .

228. See, e.g., Morgan v. Kerrigan, 530 F.2d 401 (1st Cir.), cert. denied, 426 U.S. 935 (1976); United States v. Board of School Comm'rs, 503 F.2d 68 (7th Cir. 1974), cert. denied, 421 U.S. 929 (1975); Lee v. Macon County Bd. of Educ., 448 F.2d 746 (5th Cir. 1971); Hart v. Community School Bd., 383 F. Supp. 699 (E.D.N.Y. 1974), affd, 512 F.2d 37 (2d Cir. 1975); Note, White Flight as a Factor in Desegregation Remedies: A Judicial Recognition of Reality, 66 VA. L. REV. 961 (1980).

229. 484 F.2d 1122 (2d Cir. 1973).

230. Id. at $1124-30$. 
white residents to take flight and leading eventually to non-white ghettoization of the community."231 The district court enjoined the housing authority from abandoning its regulation, ${ }^{232}$ but the Court of Appeals for the Second Circuit reversed, holding that the housing authority was under an affirmative duty to integrate and that the authority could use race-conscious inethods, including the suspension of its own regulations, to prevent tipping that would interfere with the authority's "duty to maintain racial integration."'233

The Second Circuit followed its Otero ruling in Parent Association v. Ambach, 234 in which the Queens School Board adopted a plan allowing mimority students to enroll in any school in which white student enrollment exceeded $50 \% .{ }^{235}$ In approving the limitations on enrollinent in schools with less than $50 \%$ white populations, the Ambach court openly acknowledged that its ruling permitted state use of racial criteria in a manner that unfavorably and disproportionately affected minorities, and that the state's action was predicated on the "unpleasant realities" of white flight. ${ }^{236}$ Nevertheless, the court distinguished Monroe and Scotland Neck because in those cases consideration of the avoidance of white fliglit "involved resistance to a pre-existing duty to desegregate."237 In Monroe and Scotland Neck, the court stated, the motivating concern was protecting "the interests of the whites seeking to accommodate their own prejudice."238 By contrast, the court argued, the quotas imposed in Otero and Ambach were "voluntary plan[s] which would improve the racial balance" in the affected schools and neighborhoods. ${ }^{239}$

In Johnson v. Board of Education 240 the Court of Appeals for the Seventh Circuit followed the Ambach reasoning, upholding racial quotas for minority student attendance imposed in the Chicago secondary

231. Id. at 1124.

232. The lower court decision was decided in two stages by two different district judges. See Otero v. New York City Hous. Auth., 344 F. Supp. 737 (S.D.N.Y. 1972) (prelinninary injunction issued); Otero v. New York City Hous. Auth., 354 F. Supp. 941 (S.D.N.Y.) (permanent injunction ordered), rev'd, 484 F.2d 1122 (2d Cir. 1973). For a summary of the complex listory of the Otero hitigation, see Ackerman, supra note 2, at 298-303.

233. $484 \mathrm{~F} .2 \mathrm{~d}$ at 1125.

234. 598 F.2d 705 (2d Cir. 1979).

235. Id. at 711 .

236. Id. at 719 .

237. Id.

238. Id.

239. Id. (quoting Higgins v. Board of Educ., 508 F.2d 779, 794 (6th Cir. 1974)) (emphasis in original).

240. 604 F.2d 504 (7th Cir. 1979), vacated and remanded for further consideration in light of suggestion of mootness, 449 U.S. 915 (1980). 
schools to reduce white flight.241 In language similar to that of Ambach, the Seventh Circuit atteinpted to distinguish Monroe and Scotland Neck by claiming that in those cases the primary motivation was preserving "the interests of white students seeking to accommodate their own prejudice-the disinclination to attend school with black students." 242 The court then found that the Chicago School Board's actions were not motivated by prejudice and that the restrictions were therefore constitutional. ${ }^{243}$

The decisions in Otero, Ambach, and Johnson are understandable as opinions by courts sensitive to the problems of resegregation in urban schools and communities and sympathetic to the efforts of local governments to address those problems in a practical way. The decisions do not, however, meaningfully distinguish Brown II, Monroe, and Scotland Neck. As a logical inatter, community prejudices are not tahismanically purged froin existence inerely because they filter through the inediun of a government body acting in good faith. No anount of good faith on behalf of the representative body can erase its acquiescence to the subjective fears and prejudices of the community. To the extent that Otero, Johnson, and Ambach approve restrictions on black opportunity to avoid community opposition, they are indefensible. White flight is siniply community fear and opposition translated into action, and it is not coustitutionally defensible for governments to limit minority group opportunity in order to pacify that opposition.

2. Racial Balance in Housing as an End in Itself. Although the Constitution is not color-blind, Bakke, ${ }^{244}$ Fullilove, ${ }^{245}$ and the equal protection cases that preceded then appear to reject the proposition that government nray pursue an "ideal" level of racial balance as an end in itself. The Suprenie Court has allowed government to use race as a tool only to achieve educational or economic objectives that the Court beheves are directly linked to overcoming past discrimination

241. 604 F.2d at 518.

242. Id. at 516 .

243. Id. The Court of Appeals for the Sixth Circuit discussed the connection between white flight, white prejudice, and voluntary school board activity in Higgins v. Board of Educ., 508 F.2d 779 (6th Cir. 1974), a decision affirming a district court finding that the school system of Grand Rapids, Michigan had not engaged in purposeful unconstitutional activity. The court's views as expressed in Higgins parallel those in Ambach and Johnson: "[T]here is a valid distinction between using the defense of white flight as a smokescreen to avoid integration and realistically considering and dealing with the practical problems involved in making voluntary efforts to achieve integration." Id. at 794.

244. Regents of the Univ. of Cal. v. Bakke, 438 U.S. 265 (1978). See text accompanying notes 61-66 supra.

245. Fullilove v. Klutznick, 448 U.S. 448 (1980). See text accompanying notes 67-72 supra. 
against minority groups. Each time the Court has approved the government's limited use of race, it has emphasized its belief that a logical link exists between the racial policies of the government program and the objective of remedying the effects of prior racial prejudice. In those cases the Court has also found that the government program uses race as a tool to eliminate the effects of prior prejudice in a manner devoid of stigmatizing racial stereotypes and without adverse effects on members of any racial minority. The Court has never approved the utilitarian notion that race may be used to circumscribe minority rights in the interest of the "greater good."

In Swann v. Charlotte-Mecklenburg Board of Education, 246 Chief Justice Burger, writing for a unanimous Court, stated that school boards could voluntarily adopt prescribed ratios of black students to white students for eacli school within a systein, even in the absence of a constitutional violation. ${ }^{247}$ Chief Justice Burger noted, lowever, that the Court would not approve the notion that there is a "substantive constitutional right" to "any particular degree of racial balance of mixing . . . "248 He acknowledged, however, the power of a school board faced with a history of segregation to use its awareness of the racial imbalance as a starting point for voluntarily dismantling a dual school systein. ${ }^{249}$

Similarly, Justice Powell in Bakke approvcd of the government's pursuit of pluralisin in education, writing that "the attaminent of a diverse student body. . . clearly is a constitutionally permissible goal for an institution of higher education."250. Powell proceeded, however, to focus on the distinction between educational pluralism and racial balance for its own sake. That distinction is the crucial point in his opinion and thus in the judgment of the Bakke Court. Powell stated that the Davis Medical School's pursuit of ethric pluralism was permissible only as "one element in a range of factors a university properly may consider in attaining the goal of a heterogeneous student body."251 By contrast, ethric pluralism pursued for its own sake is neither a coinpelling state interest, nor a constitutionally permissible goal: "[p]referring members of any one group for no reason other than race or ethuric origin is discrimination for its own sake. This the Constitution forbids." 252 '

246. 402 U.S. 1 (1971).

247. Id. at 16.

248. Id. at 24.

249. Id. at 25 .

250. Regents of the Univ. of Cal. v. Bakke, 438 U.S. 265, 311-12 (1978).

251. Id at 314 .

252. Id at 307. 
Describing race as one in a wide range of factors that should be considered in the interest of academic pluralism-a factor incident to developing a student body capable of enjoying a robust exchange of ideas and perspectives-Powell rejected the argument that the permissible educational pursuit of diversity requires reserving a specified number of spaces for a given racial group. On the contrary, Powell argued that a specific racial quota hinders the attainment of true diversity. 253

Nothing in the majority coalition in Fullilove modifies the Bakke holding that the government's pursuit of racial diversity for its own sake is constitutionally proscribed. Although the six Justices who voted to uphold the minority business enterprise (MBE) provision differed in their characterizations of the congressional purpose as "compelling," "substantial," or merely "legitimate," they uniformly agreed on the congressional purpose. ${ }^{254}$ They characterized the MBE program as a strictly remedial measure, aimed at the elimination of barriers to minority-firm access to public contracting opportunities.255 The Court concluded that Congress's aim was to achieve equahity of opportunity only, through race-conscious means tailored to eliminate the lingering effects of past discrimination that continued to make opportunity unequal. ${ }^{256}$

Justice Powell's concurring opinion in Fullilove emphatically reaffirmed the position that racial preference per se "can never constitute a compelling state interest."257 After concluding that the MBE program permissibly addressed the interest of ameliorating the effects of past discrimination, Powell emphasized that he continued to adhere to the position that racial classifications cannot "be imposed sinuply to serve transient social or political goals, however worthy they may be."258

253. In rejecting the idea of specific quotas, Justice Powell wrote:

[T] he argument misconceives the nature of the state interest that would justify consideration of race or ethnic background. It is not an interest in simple ethnic diversity, in which a specified percentage of the student body is in effect guaranteed to be members of selected ethnic groups, with the remaining percentage an undifferentiated aggregation of students. The diversity that furthers a compeling state interest encompasses a far broader array of qualifications and characteristics of which racial or ethnic origin is but a single though important element. Petitioner's special admission program, focused solely on ethnic diversity, would hinder rather than further attainment of genuine diversity.

Id. at 315 (footnote omitted) (emphasis added).

254. See text accompanying notes 69-72 supra.

255. Fullilove v. Klutznick, 448 U.S. 448, 463 (1980) (Burger, C.J.); id. at 511-13 (Powell, J., concurring); id. at 521 (Marshall, J., concurring).

256. Id. at 477-89.

257. Id. at 497 (Powell, J., concurring).

258. Id. at 516 (Powell, J., concurring). 
A major tenet of Bakke and Fullilove, then, is that the Constitution is at least partially color-blind, in the sense that it forbids the pursuit by government of any racial policy other than eradicating the vestiges of past racial prejudice. Despite the temptation for local governments to design populations with "ideal" racial balances, the Constitution forbids such activity, even if it is conducted im the benign pursuit of the "greater good."

\section{H. Race-Consciousness and the Real Estate Industry.}

The final objection to integration mamtenance is a pragmatic one that has both statutory and constitutional relevance. Rather than contributing to reduction of race-consciousness in housing, integrationmaintenance programs may inadvertently perpetuate the private discrimination that fair-housing laws are intended to elimmate and implicate government im the public discrimination that the Constitution forbids. The unintended effect of integration maintenance is manifest in the impact of such plans on the daily conduct of real estate brokers and white homeowners.

From the average real estate agent's pragmatic perspective, it makes no difference whether scholars or courts using fine distinctions can reconcile integration maintenance with Title VIII. Translated imto real-world conduct, integration mamtenance requires race-conscious behavior, but Title VIII forbids it, and there is a serious danger that the unintended effect of integration mamtenance is to cause theoretically benign race-conscious behavior to spill over imto situations where the race-consciousness is in fact not benign.

Government activity need not be coercive or inflexible to run afoul of the anti-discrimination principle. ${ }^{259}$ A low threshold of "encouragement" of racially selcctive activity can be sufficient to render a program illegal. In Reitman v. Mulkey, ${ }^{260}$ the voters of Califorina approved a statewide referendun known as Proposition 14, which repealed two sections of the Califorina Civil Code that banned racial discrimination in the sale of residential property. ${ }^{261}$ Proposition 14 did notling more than render the California Code facially neutral as to housing discrimination. ${ }^{262}$ The California Supreme Court considered Proposition 14 in

259. See, e.g., Jones v. Alfred H. Mayer Co., 392 U.S. 409, 421 (1968); Fox v. United States Dep't of Hous. and Urban Dev., 468 F. Supp. 907 (E.D. Pa. 1979); United States v. Reece, 457 F. Supp. 43 (D. Mont. 1978); Zuch v. Hussey, 394 F. Supp. 1028 (E.D. Mich. 1975), affd, 547 F.2d 1168 (6th Cir. 1977); United States v. Real Estate Dev. Corp., 347 F. Supp. 776 (N.D. Miss. 1972); Note, supra note 103. See notes 91-103 supra and acconipanying text.

260. 387 U.S. 369 (1967).

261. Id. at 374 .

262. See id. at 371 n.2. 
light of its "immediate objective," its "ultimate effect," and its "historical context," and struck down the referendum because it encouraged differential racial treatment. ${ }^{263}$ The United States Supreme Court affirned, approving the doctrine that a law may be violative of the fourteenth amendment " "even where the State can be charged with only encouraging,' rather than commanding discrimination."264

The Court extended the Reitman reasoning in Hunter v. Erickson, ${ }^{265}$ in which voters in Akron, Ohio, amended their city charter to provide that any fair-housing ordinance enacted by the city council regulatimg real estate transactions "on the basis of race, color, rehgion, national origims or ancestry inust first be approved by a majority of the [voters]." 266 The City of Akron tried to defend the provision by arguing that it did not affirmatively encourage discrimination or prohibit fair-housing ordinances. The Court rejected these defenses. ${ }^{267}$ Writing for the Court, Justice White stated that the charter was illegal because it created "an explicitly racial classification treating racial housing matters differently from other racial and housing matters."268

Once a town council has passed an integration-maintenance plan, the average real estate agent must decide how the council imtended for him to respond to imquiries froin prospective black entrants. If the individual real estate agent is hostile to assistmg black entry to predominantly white neighborhoods, the adoption of an integrationmamtenance plan will probably reinforce his prior prejudices by lendmg an appearance of official approval to discriminatory activity, even when the council's ideological justification for the ordinance is "benign." In choosmg between the anti-discrimination policies of Title VIII and the encouragement of discrimination implicit in the local integration-maintenance ordimance, those brokers who are inclined to discriminate invidiously will now proceed on the assumption that they have legal license to do so.

The integration-maintenance ordinance will force the real estate agent who is amenable to assisting black entry to be color-conscious in his daily activities. To comply with the local law, an agent will have to classify each prospective buyer by race and gear his sales efforts accordingly. Furthermore, to eliminate the threat of white flight, the root

263. Mulkey v. Reitman, 64 Cal. 2d 529, 413 P.2d 825, 50 Cal. Rptr. 881 (1966), aff $d$, 387 U.S. 369 (1967).

264. Reitman v. Mulkey, 387 U.S. 369, 375 (1967) (quoting Mulkey v. Reitman, 64 Cal. 2d 529, 540, 413 P.2d 825, 832, 50 Cal. Rptr. 881, 888 (1966), affd, 387 U.S. 369 (1967)).

265. 393 U.S. 385 (1969).

266. Id. at 387.

267. Id . at 389.

268. Id. 
concern of the integration-maintenance ordmance, an agent who is free from racial prejudice must act as if he is not.

Government should clearly and unequivocally tell real estate agents whether they may ever consider race in the sale of real estate. An agent's conduct should not change as he crosses a patchwork of suburban communities-shifting from color-blindness in Fair Oaks, where no imtegration-maintenance statute exists, to "benign discouragement" of blacks in Fair Elins, where an ordmance is in effect. More importantly, government should speak to the real estate agent with an internally consistent nnoral imperative. White prejudice against black entry is no excuse for an agent's refusing to show blacks homes in a white neighborhood. Agents should not be told that the excuse is sometimes valid and sometimes not, depending on whether a community has formalized its fears in a restrictive ordinance.

Since the passage of Title VIIl, the Department of Housing and Urban Development and the leadership in the real estate industry have undertaken substantial efforts to educate brokers to treat customers cqually regardless of race. The federal government and organizations such as the National Association of Realtors have distributed numerous reports, pamphlets, booklets, menioranda, notices, and posters to convince real estate agents to treat all customers equally. ${ }^{269}$ Article 10 of the Realtor's Code of Ethics states that the realtor "shall not deny equal professional services to any person for reasons of race, creed, sex or country of national origm."'270

The sponsors of Title VIII understood that the government should act as a teacher. The lesson is that the nation should commit itself to the elimination of race as a consideration in the daily decisions of the housing industry. ${ }^{271}$ The norm has been well stated by Professor William Van Alstyne:

[O]ne gets beyond racism by getting beyond it now: by a complete, resolute, and credible commitment never to tolerate in one's own life - or in the life and practices of one's government-the differential treatment of other human beings by race. Indeed, that is the great lesson for government itself to teach: im all we do im hife, to treat any person less well than another or to favor one any more than another for being black or white or brown or red, is wrong. ${ }^{272}$

269. See, e.g., 24 C.F.R. $\S \S 109.1-.3$ (1981) (advertising guidelines); 24 C.F.R. $\$ \S 110.1-.3$ (1981) (fair housing posters); MEMBER SERvs. Dep'T, National Ass'N OF REALtors, Equal OpPortunity Committee Handbook (1978); National Ass'N of Realtors, AfFirmative MARKETING HANDBOOK (1975).

270. Code of Ethics, National Ass'N of Realtors Art. 10, reprinted in National ass'N of ReAltors, AfFirmative MARKETING HaNdBOOK 65 (1975).

271. See Dubofsky, supra note 115 , at 154.

272. Van Alstyne, supra note 60, at 809-10. 
To be sure, progress in eliminating race-consciousness in housing has been painstakingly slow. But the vision should not be surrendered because it is difficult to achieve. Local governments should not be permitted to undercut Title VIII and the inassive educational effort that has followed it by reintroducing the precise type of racial thinking that Title VIII was enacted to eliminate. To be effective, Title VIII inust be accepted in letter and spirit by the real estate industry. In the practical world of the average real estate agent, the norms of behavior that Title VIII mandates are incompatible with the conduct that integration mamtenance requires. For this reason alone integration maintenance should not be permitted.

\section{CONCLUSION}

For inany it may be painful to accept the notion that the Constitution does not permit integration maimtenance, because this conclusion appears to condemn large metropolitan areas to a vicious cycle of endless resegregation. Programs that limit or discourage black entry to keep the black population beneath the tipping point may seem to be laudable governmental exercises in benevolent common sense. The constitutional objections to integration maintenance, however, are too numerous and too strong to overcome. The concept impermissibly involves government in the pursuit of an ideal racial balance and inadvertently reinforces the prejudices and fears of whites who threaten to leave areas experiencing black entry. Integration maintenance sacrifices the individual freedoms of blacks and undercuts efforts to eliminate discrimination in housing. Governments, local institutions, and influential local leaders can and should caution agamst racial panic and encourage white residents to accept black entry. Government has no legitimate interest, however, in defining social ills in terms of racial identity and employing mechanisms that impose differential racial treatment to determine who is and who is not welcome in a commumity. 
, 